\title{
Comprehensive Phytochemical Profiling of Polyherbal Divya-Kayakalp-Vati and Divya-Kayakalp-Oil and Their Combined Efficacy in Mouse Model of Atopic Dermatitis-Like Inflammation Through Regulation of Cytokines
}

\author{
Acharya Balkrishna',2, Sudeep Verma', Sachin Sakat', Kheemraj Joshi', \\ Siva K Solleti', Kunal Bhattacharya', Anurag Varshney (D) ${ }^{1,2}$ \\ 'Drug Discovery and Development Division, Patanjali Research Institute, Haridwar, 249 405, Uttarakhand, India; \\ ${ }^{2}$ Department of Allied and Applied Sciences, University of Patanjali, Patanjali YogPeeth, Haridwar, 249 405, Uttarakhand, \\ India
}

Correspondence: Anurag Varshney, Drug Discovery and Development Division, Patanjali Research Institute, NH-58, Haridwar, 249405, Uttarakhand, India, Tel +9I 1334-244I07 x7458, Fax +9l 1334 244805, Email anurag@prft.co.in

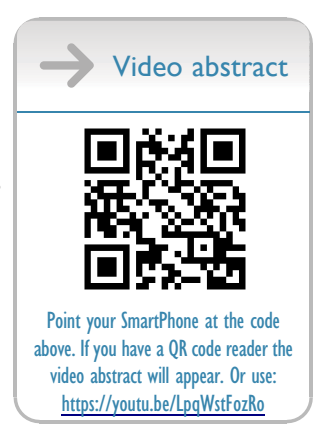

Purpose: Atopic dermatitis (AD) is a chronic inflammatory disease that varies in signs and symptoms in different individuals. General symptoms include dryness of the skin, itching, and development of red to brownish-gray patches. Divya-Kayakalp-Vati (DKV) and -Oil (DKO) are Indian polyherbal compositions prescribed for treating inflammatory skin diseases. In the present study, we evaluated the anti-inflammatory efficacy of DKV and DKO co-treatment (DKV-O) in ameliorating Oxazolone (OXA)-stimulated ADlike inflammation and pro-inflammatory cytokine release in a Swiss albino mouse model.

Methods: Phytochemical profiling of the DKV and DKO were done using Liquid Chromatography-Mass Spectroscopy (LC-MS) QToF. Swiss albino mice were sensitized for 7 days and treated with OXA in their ear region. Stimulated and control animals were orally treated with DKV and topically with DKO. Anti-inflammatory efficacy of DKV-O was determined in OXA-treated animals through physiological, histopathological, and biochemical parameter analysis.

Results: DKV and DKO formulations individually contained 39 and 59 phytochemicals, respectively. Many of the phytochemicals have been reported to have anti-inflammatory activities. In the OXA-sensitized Swiss albino mice, combined treatment with DKV-O, and separately with Dexamethasone (positive control) significantly reduced the OXA-stimulated ear edema, biopsy weight, and epidermal thickness. DKV-O further reduced OXA-stimulated induction of inflammatory lesions, neutrophil influx, and release of Interleukin (IL)-1 $\beta$, IL-6, tumor necrosis factor- $\alpha$, and myeloperoxidase.

Conclusion: Finally, DKV-O co-treatment showed good pharmacological effects in ameliorating AD-like inflammation through the modulation of inflammatory cell influx and release of soluble mediators. Therefore, DKV-O treatment can be used as a suitable polyherbal therapeutic against AD-like inflammatory diseases.

Keywords: inflammation, oxazolone, phytochemical profile, pro-inflammatory cytokines, histopathological analysis, biochemical analysis

\section{Introduction}

Atopic Dermatitis (AD) is a dermal inflammatory condition varying in symptoms for individual patients. Common symptoms associated with the disease include skin dryness and itching, red to brownish-gray scaly patches on limbs, 
neck, upper chest, and eyelid regions. AD often occurs in children $\geq 6$ years persisting until adolescence and adulthood. ${ }^{1,2}$ The disease may flare up occasionally and then clear up by itself after some time.

Exaggerated T helper-2 (Th2) cells-mediated immune-pathway activation in combination with exposure to environmental factors, neuropsychological factors, epidermal barrier deficiency, and microbial pathogens lead to the inception of $\mathrm{AD}^{3-5}$ Incidences of $\mathrm{AD}$ have increased several times over the past 30 years affecting $20 \%$ of children and $2 \%$ of adults. $^{6}$ Approximately, $70-80 \%$ of $\mathrm{AD}$ patients, show an elevated serum IgE level with high sensitization towards environmental allergens. While remaining $20-30 \%$ of patients show an "intrinsic" form of AD with low serum IgE levels. ${ }^{7}$ Early development of AD during infancy can be attributed to IgE sensitization to food allergens. Sharing of inflammatory pathways between $\mathrm{AD}$ and other immunomodulatory diseases may also lead to the development of allergic rhinitis and asthma in later part of patient's life.$^{8-10}$ At a molecular level, AD is associated with gene mutations affecting epidermal differentiation, and skin barrier formation. ${ }^{11-13}$

Based on age, ethnicity, and biological mechanism, AD presents varying clinical pathologies. In an Italian multicentric retrospective cohort clinical study, Nettis et al showed the prevalence of lichenified/ exudative flexural AD in children often associated with head, neck, and hand eczema. ${ }^{14}$ In adults, besides the presence of lichenified/ exudative flexural dermatitis, they also showed the presence of prurigo nodularis-like AD characterized by distinct, intensely itching papules and nodules dominant in the limbs and back parts of the body, and nummular eczema-like phenotype presents with eczematous, sometimes "weeping" lesions and is often associated with cutaneous xerosis. ${ }^{14}$

Due to the chronic and recurrent nature of $\mathrm{AD}$, long-term therapies and medications are necessary for treating the disease. Tofacitinib and Baricitinib act as inhibitors for JAK-based immune responses. ${ }^{15}$ Calcineurin inhibitors, and cAMP-specific 3',5'-cyclic phosphodiesterase-4 inhibitors, and biologics like Lebrikizumab, Apremilast, Crisaborole, Dupilumab, and IL-31 are generally applied as immunomodulators against AD. ${ }^{16-22}$ However, some of them may have unwanted health-related side effects. ${ }^{23}$ Divya-Kayakalp-Vati (DKV) and -Oil (DKO) are polyherbal Ayurvedic formulations, suggested having efficacy in treating skin inflammatory disorders. DKV and DKO, formulated according to the ancient Indian texts of Charak Samhita, are composed of 18 different plants detailed under Table $1 .{ }^{24-26}$ Earlier, a combined DKV and DKO (DKV-O) treatment has shown immunomodulatory activity in $\lambda$-carrageenan-stimulated Wistar rats paw edema model and 12-O-tetradecanoylphorbol 13-acetate (TPA)-treated CD-1 mouse ear edema model. ${ }^{27}$ Anti-inflammatory efficacy of DKV-O was observed to originate from the phytochemical constituents present within.

Different experimental mouse models have been employed for the study of AD, such as 1) animals stimulated with the epicutaneous application of sensitizers, 2) transgenic mice overexpressing or lacking selective molecules, and 3) mice showing spontaneous development of AD-like skin lesions. ${ }^{5}$ Oxazolone (OXA) is a Hapten that is used for evoking ADlike inflammation primarily through an epidermal barrier breach, and Th1-dominated initial response that later shifts to Th2-type response, similar to human AD. ${ }^{28}$ OXA challenge has been reported to induce the development of epidermal hyperplasia and reduce expression of the skin differentiation proteins- filaggrin, loricrin, and involucrin. ${ }^{5}$

The present study investigates the pharmacological effects of DKV-O at a human equivalent dose in Swiss Albino mice challenged with OXA and eliciting AD-like dermal inflammation. Histological analysis parameters included ear edema, biopsy weight, epidermal thickness, and modulation of inflammatory lesions. Additionally, circulating serum biomarkers for inflammation were also analyzed. We preluded the study with an in-depth phytochemical analysis of DKV and DKO and correlated those findings to the biological study outcomes.

\section{Materials and Methods}

\section{Reagents}

Divya-Kayakalp-Vati (Batch no. A-KKVE090) and Divya-Kayakalp-Oil (Batch no. BKKT056) were sourced from Divya Pharmacy (Haridwar, Uttarakhand, India). Their herbal compositions were provided by the manufacturer (Table 1). Oxalozone (OXA; Purity 99.9\%), Dexamethasone (DEXA; Purity 99.9\%), and 3,3',5,5'-Tetramethylbenzidine were purchased from Sigma-Aldrich (St. Louis, MO, USA). ELISA reagents for IL-1 $\beta$, IL-6, and TNF- $\alpha$ analysis were purchased from BD Biosciences (San Jose, CA, USA). HPLC grade acetonitrile, ortho-phosphoric acid, and diethylamine 
Table I Complete Herbal Composition of Divya-Kayakalp-Vati (DKV) and Divya-Kayakalp-Oil (DKO)

\begin{tabular}{|c|c|c|c|c|c|}
\hline S.No. & English Name & Latin Name (Family) & DKV (mg) & DKO (mg) & DKO (mL) \\
\hline I & Ringworm plant & Cassia tora L. (Caesalpiniaceae) & 30 & 30 & \\
\hline 2 & Turmeric & Curcuma longa L. (Zingiberaceae) & 30 & 30 & \\
\hline 3 & Indian laburnum & Hemidesmus indicus (L.) R. Br. (Periplocaceae) & 30 & 30 & \\
\hline 4 & Indian barberry & Berberis aristata DC. (Berberidaceae) & 30 & 30 & \\
\hline 5 & Margosa & Azadirachta indica A. Juss. (Meliaceae) & 30 & 30 & \\
\hline 6 & Indian Gooseberry & Emblica officinalis Gaertn. (Euphorbiaceae) & 30 & 30 & \\
\hline 7 & Indian Madder & Rubia cordifolia L. (Rubiaceae) & 25 & 25 & \\
\hline 8 & Heart-leaved moonseed & $\begin{array}{l}\text { Tinospora cordifolia (Willd.) Hoof. f. and Thomson } \\
\text { (Menispermaceae) }\end{array}$ & 20 & & \\
\hline 9 & Spider wort & Leucas cephalotes (Roth) Spreng. (Lamiaceae) & 10 & 10 & \\
\hline 10 & $\begin{array}{c}\text { Mexican poppy yellow } \\
\text { thistle }\end{array}$ & Argemone Mexicana L. (Papaveraceae) & 10 & & \\
\hline II & Cutch tree & Acacia catechu (L.f.) Willd. (Leguminosae) & 5 & & \\
\hline 12 & Sandalwood white & Santalum album L. (Santalaceae) & & 10 & \\
\hline 13 & Colocynth/ Bitter Apple & Citrullus colocynthis (L.) Schrad. (Cucurbitaceae) & & 10 & \\
\hline 14 & Himalayan deodar & Cedrus deodara (Roxb. ex D. Don) G. Don (Pinaceae) & & 10 & \\
\hline 15 & Sarsaparilla & Smilax ornate Lem. (Smilacaceae) & & 10 & \\
\hline 17 & Mustard oil & Brassica campestris L. (Brassicaceae) & & & 100 \\
\hline 18 & Ironweed & Centratherum anthelminticum (L.) Kuntze (Asteraceae) & & 10 & \\
\hline \multicolumn{6}{|c|}{ Excipients } \\
\hline $\mathbf{I}$ & Gum arabica (Exudate) & Acacia arabica (Lam.) Willd. (Fabaceae) & 12.5 & & \\
\hline 2 & Talcum (Powder) & & 2.5 & & \\
\hline 3 & Aerosil (Powder) & & 2 & & \\
\hline
\end{tabular}

along with hematoxylin and Eosin (H\&E) stains were purchased from Merck (Kenilworth, NJ, USA). All other chemicals and reagents purchased for the study were of the highest commercial grade.

\section{Sample Preparation for DKO and DKV}

Ninety grams of DKO were suspended in $200 \mathrm{~mL}$ of $90 \%$ aqueous methanol. The solution was stirred for $1 \mathrm{~h}$ using a magnetic stirrer and stored at $-20^{\circ} \mathrm{C}$ for 2 days. Following separation of the methanol from the frozen oil layer, it was removed manually. Finally, the DKO sample was thawed, filtered, and dried using Rotavapor. Obtained DKO residue $(0.66 \mathrm{~g})$ was resuspended in $90 \%$ aqueous methanol at the final volume of $10 \mathrm{~mL}$ and filtered through a $0.45 \mu \mathrm{m}$ PTFE membrane filter (Millipore, Burlington, MA, USA), and stored until further use for LC-MS QToF analysis. One gram of DKV powder was dissolved in $40 \mathrm{~mL}$ of hydromethanolic solution and sonicated for $15 \mathrm{~min}$. The hydromethanolic DKV suspension was centrifuged at $5000 \mathrm{rpm}$ for $5 \mathrm{~min}$. Approximately, $0.50 \mathrm{~mL}$ of the clear upper layer was collected and diluted further for LC-MS QToF analysis. 


\section{Liquid Chromatography (LC-MS) QToF Analysis}

LC-MS QToF analysis was performed on a Xevo G2-XS QToF with Acquity UPLC- I Class and analyzed using Unifi Scientific Information System software (Waters Corporation, Milford, MA, USA). Separation was carried out using Acquity UPLC HSS -T3 column $(100 \times 2.10 \mathrm{~mm}, 1.70 \mu \mathrm{m})$ maintained at $50^{\circ} \mathrm{C}$. The sample temperature was kept at $10^{\circ} \mathrm{C}$ during the analysis. Elution was carried out at a flow rate of $0.40 \mathrm{~mL} / \mathrm{min}$ using gradient elution of mobile Phase $0.1 \%$ formic acid in water (mobile phase A) and $0.1 \%$ formic acid in acetonitrile (mobile phase B). $1 \mu \mathrm{L}$ of test solution (either DKV or DKO) was injected and the chromatograph was recorded for $55 \mathrm{~min}$.

\section{Experimental Animals}

Swiss albino mice (6-8 weeks) were procured from Charles River Laboratory licensed supplier Hylasco Biotechnology Pvt. Ltd. (Hyderabad, India). All the animals were placed under a controlled environment with $60-70 \%$ relative humidity and 12:12 $\mathrm{h}$ light and dark cycle in a registered animal house (1964/PO/RC/S/17/CPCSEA) of Patanjali Research Institute, India. The animals were fed a standard pellet diet (Golden Feed, India) and sterile filtered water ad libitum. The animal study protocol was approved by the Institutional Animal Ethical Committee (IAEC) of Patanjali Research Institute vide approval number: PRIAS/LAF/IAEC-023. Experimental procedures and animal husbandry practices were strictly conformed to the CPCSEA standards. ${ }^{29}$ The study was conducted in compliance with The ARRIVE guidelines. ${ }^{30}$ Eight animals were randomly allocated to each study group.

\section{In-vivo Evaluation of DKV-O Against Atopic Dermatitis (AD)-Like Inflammation} Mice Model of Oxazolone Induced AD-Like Inflammation

The combined therapeutic effect of DKV and DKO was analyzed in the OXA-stimulated AD-like inflammation mice model at human equivalent doses as described earlier. ${ }^{31}$ Briefly, 1.5\% OXA solution was prepared by mixing it in acetone (vehicle). Mice were sensitized in their clipped abdomen to $1.5 \%$ OXA by applying $100 \mu \mathrm{L}$ solution for 7 days. The mice were then challenged with 1.5\% OXA (20 $\mu$ L T.A.) in the ear region. Ear thickness was measured at 0, 6, 24, 48, and $72 \mathrm{~h}$ using a digital Vernier caliper (Mitutoyo, Tokyo, Japan) (Figure 1). Treatment group mice were given vehicle alone (acetone, P.O.), or DKV $(150 \mathrm{mg} / \mathrm{kg}$; P.O.) and DKO (20 $\mu \mathrm{L}$ T.A.), or DEXA ( $0.2 \mathrm{mg} / \mathrm{kg}$; P.O.) throughout the experimental period. Unchallenged OXA-sensitized mice were considered normal control (NC), and untreated OXA challenged mice were considered disease

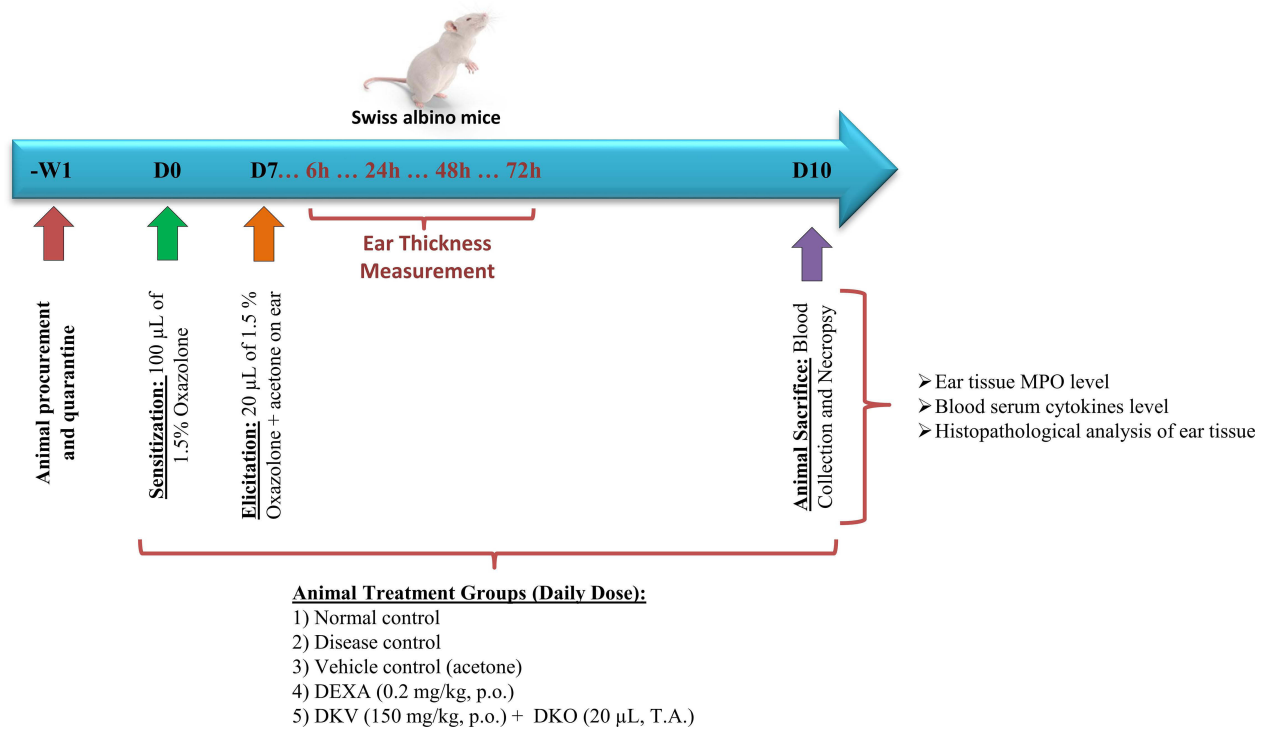

Figure I Study design for pharmacology study of Divya-Kayakalp-Vati (DKV) and Oil (DKV). Swiss albino mice were procured and acclimatized for one week. Mice were sensitized in their clipped abdomen against 1.5\% Oxazolone (OXA; $100 \mu \mathrm{L}$ ) for 7 days. Later, mice were challenged with I.5\% OXA (T.A.) on their ear ( $20 \mu \mathrm{L} /$ ear). Ear thickness was measured at $0,6,24,48$, and $72 \mathrm{~h}$ using a digital Vernier caliper. Animals were treated daily with DKV ( $150 \mathrm{mg} / \mathrm{kg}$; P.O.) and DKO (20 $\mu \mathrm{L}$ T.A.), or Dexamethasone (DEXA; $0.2 \mathrm{mg} / \mathrm{kg})$. Animals were sacrificed on day 10 , and tissue and blood samples were collected for histopathological and biochemical parameters analysis. 
control (DC) in the study. Changes in ear thickness were calculated by subtracting ear thickness measure per hour from ear thickness measured at $0 \mathrm{~h}$ (Figure 1).

\section{Histopathological Analysis}

On day 10, mice were humanely sacrificed at $6 \mathrm{~h}$ post-treatment. Ear biopsy samples were weighed and fixed in $10 \%(\mathrm{v} / \mathrm{v})$ neutral buffered formalin, embedded in paraffin, and sectioned at 3-5 $\mu$ m thickness using a Leica RM2245 microtome (Wetzlar, Germany). Tissue sections were transferred to a glass slide and stained with H\&E stain. Epidermal thickness from the basal to stratum corneum layer was measured using MagVision image analysis software attached to Magcam DC5 microscopic camera. Severity of inflammatory lesions was recorded as: NAD $=$ No abnormality detected, $1=$ minimal $(<1 \%), 2=$ mild $(1-25 \%), 3=$ moderate $(26-50 \%), 4=$ moderately severe/marked $(51-75 \%), 5=$ severe $(76-100 \%)$. Distribution of the lesions was recorded as focal, multifocal, and diffused. Other parameters considered for histopathological examination were extent, hyperkeratosis, number, and size of pustules, epidermal hyperplasia (measured in the interfollicular epidermis), an influx of inflammatory cells in the dermis and soft tissue.

\section{Immuno-Biochemical Parameters}

Enzyme-linked immunosorbent assay (ELISA) was performed for determining the levels of interleukin (IL)-1 $\beta$, IL-6, and tumor necrosis factor-alpha (TNF- $\alpha$ ) in circulating animal serum samples following the manufacturer's protocol. Myeloperoxidase level in the ear biopsy samples was analyzed following the protocol mentioned by Suzuki et al, using 3.3',5,5'-tetramethylbenzidine (TMB) dye. ${ }^{32}$ Briefly, $10 \mu \mathrm{L}$ of ear biopsy homogenized samples were combined with $80 \mu \mathrm{L}$ of $0.75 \mathrm{mM} \mathrm{H}_{2} \mathrm{O}_{2}$ and $110 \mu \mathrm{L}$ of $2.9 \mathrm{mM}$ TMB solution (prepared in $14.5 \%$ dimethyl sulphoxide) and 150 $\mathrm{mM}$ sodium phosphate buffer ( $\mathrm{pH}$ 5.4) in a 96 well plate. Plate was incubated at $37^{\circ} \mathrm{C}$ for 5 min and the assay was stopped by adding $2 \mathrm{M} \mathrm{H}_{2} \mathrm{SO}_{4}$. Absorbance was obtained at $450 \mathrm{~nm}$ using the Envision microplate reader (Perkin Elmer, Waltham, MA, USA).

\section{Statistical Analysis}

Results have been presented as Mean \pm Standard Error of Mean (SEM). Statistical analysis was done using GraphPad Prism version 7.03 software (GraphPad Software Inc., San Diego, CA, USA). Two-way analysis of variance (ANOVA) followed by Newman-Keuls multiple comparison tests was used for ear edema parameter. A one-way analysis of variance (ANOVA) followed by Dunnett's multiple comparisons post-hoc tests were used for calculating statistical significance in cytokine(s) analysis, ear biopsy weights, epidermal thickness, and lesion scores parameters. Values with a p-value $<0.05$ were considered significant.

\section{Results}

A total of 39 phytochemicals in DKV and 59 phytochemicals in DKO were identified based on their retention time (RT) and mass-charge ratio (m/z) using LC-MS QToF assay. In DKV, 33 phytochemicals were identified in positive mode and 18 phytochemicals in negative mode. Twelve non-polar phytochemicals were observed in both positive and negative modes (Table 2, Figure 2A and B). In DKO, 26 phytochemicals were observed in positive mode and 31 phytochemicals in negative mode. Six phytochemicals were present in both the positive and negative modes (Table 2; Figure 3A and B). Major phytochemicals commonly detected in both DKV and DKO were 1.8-Dihydroxy-6-methoxy-3-methylanthraquinone (Physcion), Berbamine, Berberine, Catechin, Columbin, Curcumin, Ellagic acid, Gallic acid, Kaempferol, Obtusin, Palmatine, Quercetin, and Swertiamarin. Physcion has been shown to inhibit the formation of AD-related skin lesions through the blocking of thymic stromal lymphopoietin. ${ }^{33}$ Berbamine has also been shown to regulate T-cell activation and inhibit NF-kB and MAPK (JNK and ERK1/2) signaling pathways in LPS-stimulated macrophages. ${ }^{34,35}$ Similarly, other individually identified phytochemicals in DKV and DKO have reported anti-inflammatory activities.

Our in-vivo study showed a significantly elevated level of ear edema in the OXA sensitized DC mice following challenge with $1.5 \%$ OXA, as compared to NC mice (p-value $<0.01$ ) (Figure 4A). OXA-treated DC mice showed maximum swelling at $24 \mathrm{~h}(0.54 \pm 0.02 \mathrm{~mm})$ post-treatment, reaching a plateau stage that continued to be elevated with a minor change up to $72 \mathrm{~h}(0.42 \pm 0.04 \mathrm{~mm})$. Co-treatment of the OXA-stimulated mice with DKV $(150 \mathrm{mg} / \mathrm{kg}$, P.O.) and 
Table 2 Identified Phytochemicals Present in the Divya-Kayakalp-Vati (DKV) and Divya-Kayakalp-Oil (DKO) Using LC-MS QToF Analysis

\begin{tabular}{|c|c|c|c|c|c|c|c|}
\hline \multirow[t]{2}{*}{ S.No. } & \multirow[t]{2}{*}{ Name of Phytochemical Detected } & \multicolumn{3}{|c|}{ DKV } & \multicolumn{3}{|c|}{ DKO } \\
\hline & & Mode & $\begin{array}{l}\text { Retention } \\
\text { time }\end{array}$ & $\begin{array}{c}\text { Mass/ Charge } \\
(\mathrm{m} / \mathrm{z})\end{array}$ & Mode & $\begin{array}{l}\text { Retention } \\
\text { time }\end{array}$ & $\begin{array}{c}\text { Mass/ Charge } \\
(\mathrm{m} / \mathrm{z})\end{array}$ \\
\hline 1 & $\begin{array}{l}\text { I,8-Dihydroxy-3-methylanthraquinone } \\
\text { (Chrysophanol) }\end{array}$ & -ve & 9.4 & 253.05 & & & \\
\hline 2 & $\begin{array}{l}\text { I,8-Dihydroxy-6-methoxy- } \\
\text { 3-methylanthraquinone (Physcion) }\end{array}$ & -ve & 12.44 & 283.06 & $+\mathrm{ve} /-\mathrm{ve}$ & $12.45 / 12.42$ & $285.08 / 283.06$ \\
\hline 3 & 3-Methoxy-4-hydroxybenzoic acid & & & & $+\mathrm{ve} /-\mathrm{ve}$ & $5.27 / 5.22$ & $169.05 / 167.04$ \\
\hline 4 & Afzelechin & $+v e /-v e$ & 5.9 & $275.09 / 273.08$ & & & \\
\hline 5 & Alizarin & $+\mathrm{ve} /-\mathrm{ve}$ & 11.48 & $241.05 / 239.03$ & & & \\
\hline 6 & Alizarin & & & & + ve/-ve & $\mathrm{II} .5 \mathrm{I} / \mathrm{II} .48$ & $24 I .05 / 239.03$ \\
\hline 7 & Androsin & +ve & 4.82 & 351.1 & & & \\
\hline 8 & Apocynin & & & & $+\mathrm{ve}$ & 7.05 & 167.07 \\
\hline 9 & Arbutin & +ve & 8.72 & 273.1 & & & \\
\hline 10 & Arjunetin & & & & + ve/-ve & 23.1 & $651.41 / 649.39$ \\
\hline II & Arjunic acid & & & & -ve & $|4.0|$ & 487.34 \\
\hline 12 & Bavachinin & & & & -ve & 17.44 & 337.14 \\
\hline 13 & Bavachromanol & & & & -ve & 12.55 & 339.12 \\
\hline 14 & Bavachromene & & & & -ve & 12.82 & 321.11 \\
\hline 15 & Benzoic acid & & & & -ve & 7.6 & 121.03 \\
\hline 16 & Berbamine & +ve & 6.98 & 609.3 & $+\mathrm{ve}$ & 6.96 & 609.3 \\
\hline 17 & Berberine & +ve & 8.97 & 336.12 & $+\mathrm{ve}$ & 8.98 & 336.12 \\
\hline 18 & Bisdemethoxylcurcumin & & & & $+\mathrm{ve}$ & 13.04 & 309.11 \\
\hline 19 & Butin & & & & -ve & 9.94 & 271.06 \\
\hline 20 & Catalpol & $+\mathrm{ve}$ & 14.74 & 363.13 & & & \\
\hline 21 & Catechin & $+\mathrm{ve} /-\mathrm{ve}$ & $4.84 / 4.89$ & $291.09 / 289.07$ & -ve & 4.84 & 289.07 \\
\hline 22 & Citric acid & $+v e /-v e$ & 1.25 & $215.02 / 191.02$ & & & \\
\hline 23 & Columbamine & $+\mathrm{ve}$ & 8.23 & 338.14 & & & \\
\hline 24 & Columbin & $+\mathrm{ve}$ & 10.1 & 359.15 & $+v e$ & 10.02 & 359.15 \\
\hline 25 & Corylidin & & & & -ve & 10.04 & 367.08 \\
\hline 26 & Corylifolin & & & & + ve/-ve & 15.4 & $325.14 / 323.13$ \\
\hline 27 & Corylin & & & & -ve & 13.96 & 319.1 \\
\hline 28 & Courmaric acid & $+v e /-v e$ & $7.56 / 7.57$ & $|49.06 /| 47.04$ & & & \\
\hline 29 & Curcumin & $+\mathrm{ve}$ & 13.6 & 369.13 & + ve/-ve & 13.62 & $369.13 / 367.12$ \\
\hline 30 & Cyclocurcumin & $+\mathrm{ve}$ & 4.66 & 369.13 & & & \\
\hline
\end{tabular}

(Continued) 
Table 2 (Continued).

\begin{tabular}{|c|c|c|c|c|c|c|c|}
\hline \multirow{2}{*}{ S.No. } & \multirow{2}{*}{$\begin{array}{l}\text { Name of Phytochemical Detected } \\
\text { Cyclopamine }\end{array}$} & \multicolumn{3}{|c|}{ DKV } & \multicolumn{3}{|c|}{ DKO } \\
\hline & & & & & +ve & 11.45 & 412.32 \\
\hline 32 & Demethoxycurcumin & & & & +ve & 13.32 & $339.12 / 337.11$ \\
\hline 33 & Ellagic acid & -ve & 7.18 & 301 & -ve & 7.16 & 301 \\
\hline 34 & Emodin & -ve & 10.16 & 269.04 & & & \\
\hline 35 & Ethyl gallate & & & & -ve & 4.21 & 197.05 \\
\hline 36 & Euxanthone & & & & +ve & 8.96 & 229.05 \\
\hline 37 & Ferulic acid & -ve & 8.31 & 193.05 & & & \\
\hline 38 & Gallic acid & $+v e /-v e$ & $2.17 / 2.19$ & $171.03 / 169.01$ & -ve & 2.17 & 169.01 \\
\hline 39 & Gentianine & $+\mathrm{ve}$ & 6.66 & 198.05 & & & \\
\hline 40 & Gentiopicroside & $+\mathrm{ve}$ & 2.42 & 379.1 & & & \\
\hline 41 & Isobavachalcone & & & & +ve & 12.28 & 325.14 \\
\hline 42 & Isorhamnetin & $+v e /-v e$ & $9.67 / 9.69$ & $317.07 / 315.05$ & & & \\
\hline 43 & Jatrorrhizine & & & & +ve & 8.26 & 338.14 \\
\hline 44 & Kaempferol & $+v e /-v e$ & 10.3 & $287.06 / 285.04$ & $+\mathrm{ve}$ & 10.34 & 287.06 \\
\hline 45 & Lofoline & & & & +ve & 9.29 & 308.22 \\
\hline 46 & Mangiferin & $+v e /-v e$ & $5.74 / 5.76$ & $423.09 / 421.08$ & & & \\
\hline 47 & Matairesinol & & & & -ve & 10.25 & 357.13 \\
\hline 48 & Obtusifolin & $+v e$ & 9.52 & 285.08 & & & \\
\hline 49 & Obtusin & $+v e$ & 13.37 & 345.1 & $+\mathrm{ve}$ & 13.39 & $345.10 / 343.08$ \\
\hline 50 & Oxyberberine & $+v e$ & 7.63 & 352.12 & & & \\
\hline 51 & Palmatine & $+\mathrm{ve}$ & 8.91 & 352.15 & $+\mathrm{ve}$ & 8.92 & 352.15 \\
\hline 52 & Palmitamide & & & & +ve & 20.13 & 256.26 \\
\hline 53 & $\mathrm{p}$-Cresol & & & & -ve & 6.02 & 107.05 \\
\hline 54 & Phenol & & & & -ve & 7.79 & 93.036 \\
\hline 55 & Phenylacetic acid & & & & -ve & 6.32 & 135.05 \\
\hline 56 & p-Hydroxybenzoic acid & & & & -ve & 7.78 & 137.02 \\
\hline 57 & Protopine & & & & -ve & 9.99 & 352.12 \\
\hline 58 & Psoralen & & & & -ve & 7.91 & 185.02 \\
\hline 59 & Psoralenol & & & & -ve & 10.72 & 337.11 \\
\hline 60 & Psoralidin & & & & -ve & 14.32 & 335.09 \\
\hline 61 & Purpurin & $+\mathrm{ve}$ & 1.2 & 279.03 & & & \\
\hline 62 & Quercetin & $+v e /-v e$ & $9.29 / 9.31$ & $303.05 / 301.03$ & -ve & 9.29 & 301.03 \\
\hline 63 & Quercetin 3.4'-dimethyl Ether & & & & +ve & 11.5 & 331.08 \\
\hline
\end{tabular}

(Continued) 
Table 2 (Continued).

\begin{tabular}{|c|c|c|c|c|c|c|c|}
\hline \multirow{2}{*}{$\begin{array}{l}\text { S.No. } \\
64\end{array}$} & \multirow{2}{*}{$\begin{array}{l}\text { Name of Phytochemical Detected } \\
\text { Rubiadin }\end{array}$} & \multicolumn{3}{|c|}{ DKV } & \multicolumn{3}{|c|}{ DKO } \\
\hline & & +ve & 5.83 & 255.06 & & & \\
\hline 65 & Rubrofusarin & $+v e /-v e$ & $5.83 / 5.86$ & $273.08 / 271.06$ & & & \\
\hline 66 & Shikimic acid & -ve & 0.87 & 173.04 & & & \\
\hline 67 & Stigmasterol & & & & +ve & 14.28 & 413.38 \\
\hline 68 & Sweroside & +ve & 4.9 & 395.13 & & & \\
\hline 69 & Swertiamarin & +ve & 4.85 & 375.13 & -ve & 4.81 & 373.11 \\
\hline 70 & Syringaresinol & +ve & 16.29 & 419.17 & & & \\
\hline 7I & Terminolic acid & & & & -ve & 11.26 & 503.34 \\
\hline 72 & Uridine & & & & $+v e$ & 13.62 & 245.08 \\
\hline 73 & Ursolic acid & & & & -ve & 20.5 & 455.35 \\
\hline 74 & Vanillin & $+v e /-v e$ & $5.82 / 5.85$ & $153.057 / 151.04$ & & & \\
\hline 75 & Veratramine & & & & +ve & 12.72 & 410.3 \\
\hline 76 & Veronicoside & +ve & 4.85 & 467.15 & & & \\
\hline 77 & $\beta$-Amyrin & & & & $+\mathrm{ve}$ & 23.96 & 427.39 \\
\hline
\end{tabular}

Note: Spectra were collected in the positive and negative modes (see Figures $2 A$ and B, 3A and B).

DKO $(20 \mu \mathrm{L}, \mathrm{T}$.A.) $(\mathrm{DKV}-\mathrm{O})$ significantly (p-value $<0.01)$ reduced ear edema at $24 \mathrm{~h}(0.30 \pm 0.02 \mathrm{~mm})$, and $72 \mathrm{~h}(0.19 \pm$ $0.02 \mathrm{~mm}$ ) compared to DC animal (Figure 4A). DEXA $(0.2 \mathrm{mg} / \mathrm{kg}$, P.O.) treatment also significantly reduced the OXAstimulated ear edema in the mice at $24 \mathrm{~h}(0.15 \pm 0.01 \mathrm{~mm})$ and $72 \mathrm{~h}(0.11 \pm 0.01 \mathrm{~mm})$ (Figure 4A). OXA-challenge also induced a significant (p-value $<0.01)$ increase in the ear biopsy weight $(11.74 \pm 2.64 \mathrm{mg}$ ) of DC mice compared to NC animals $(5.76 \pm 0.44 \mathrm{mg}$ ) (Figure 4B). Vehicle control (VC) treated animals did not show any change $(5.41 \pm 0.86 \mathrm{mg}) \mathrm{in}$ their ear biopsy weight. Treatment of the OXA-stimulated mice with DKV-O significantly ( $p$-value $<0.01)$ reduced the induced biopsy weight $(7.44 \pm 1.09 \mathrm{mg}$ ) increase compared to the DC animals (Figure 4B). DEXA treatment also significantly (p-value $<0.01)$ reduced the OXA-stimulated increase in the ear biopsy weight $(4.44 \pm 0.86 \mathrm{mg})$ (Figure 4B).

Histopathological analysis of $\mathrm{NC}$ and $\mathrm{VC}$ mice ears showed the presence of normal tissue condition with continuous epidermal, dermal, and cartilage layers containing sebaceous glands (Figure 5A and B). Stimulation of the mice ears with OXA induced pustule formation, hyperkeratosis, and hyperplasticity in the epidermal region along with the influx of neutrophils in the dermis region (Figure 5C). This was ameliorated through treatment with DEXA showing a reduction in the epidermal region pustule formation and a reduced presence of neutrophils in the dermis region (Figure 5D). Similarly, DKV-O treatment also reduced pustule formation in the epidermal region of the OXA stimulated animals. A minor change was observed in the presence of neutrophils within the dermis region, and pustule formation in the epidermal region of the DKV-O treated OXA-stimulated animals (Figure 5E).

Based on the histopathological tissue section analysis, OXA-stimulation of the animal ears induced a significant (p-value $<0.01$ ) $41.5 \pm 14.4 \%$ increase in the ear epidermal thickness compared to the NC animals (Figure 6). No change was observed in the epidermal thickness of the mice treated with the VC only (Figure 6). DKV-O treatment of the OXAstimulated animals for 10 days significantly (p-value $<0.01$ ) reduced $(27.58 \pm 4.26 \%$ ) the induced ear epidermal thickness increase compared to the DC mice (Figure 6). DEXA treatment also significantly (p-value $<0.01)$ reduced $(8.58 \pm 1.67 \%)$ the OXA-induced epidermal thickness in the mouse ear compared to the DC mice (Figure 6). 
A

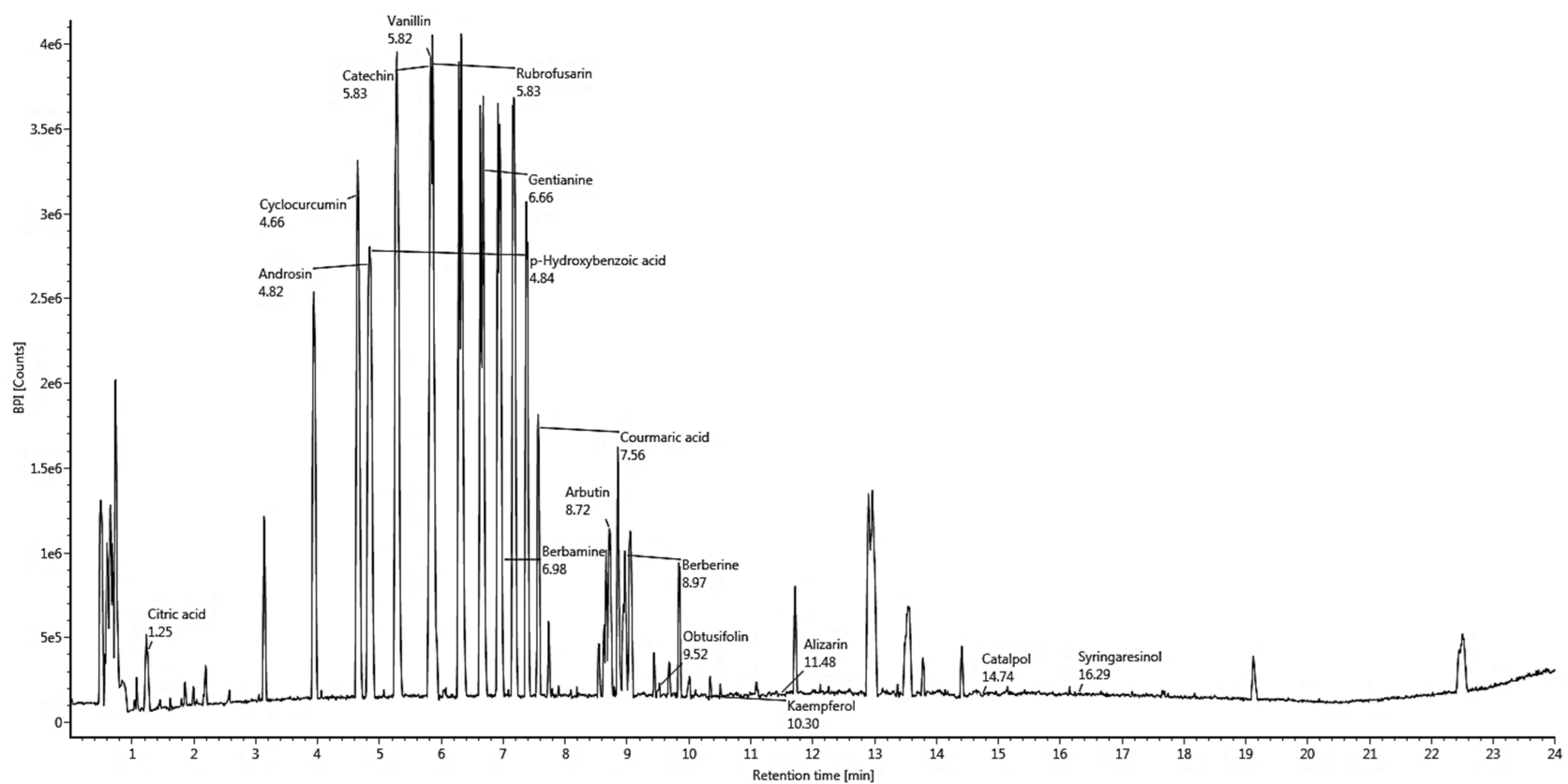

B

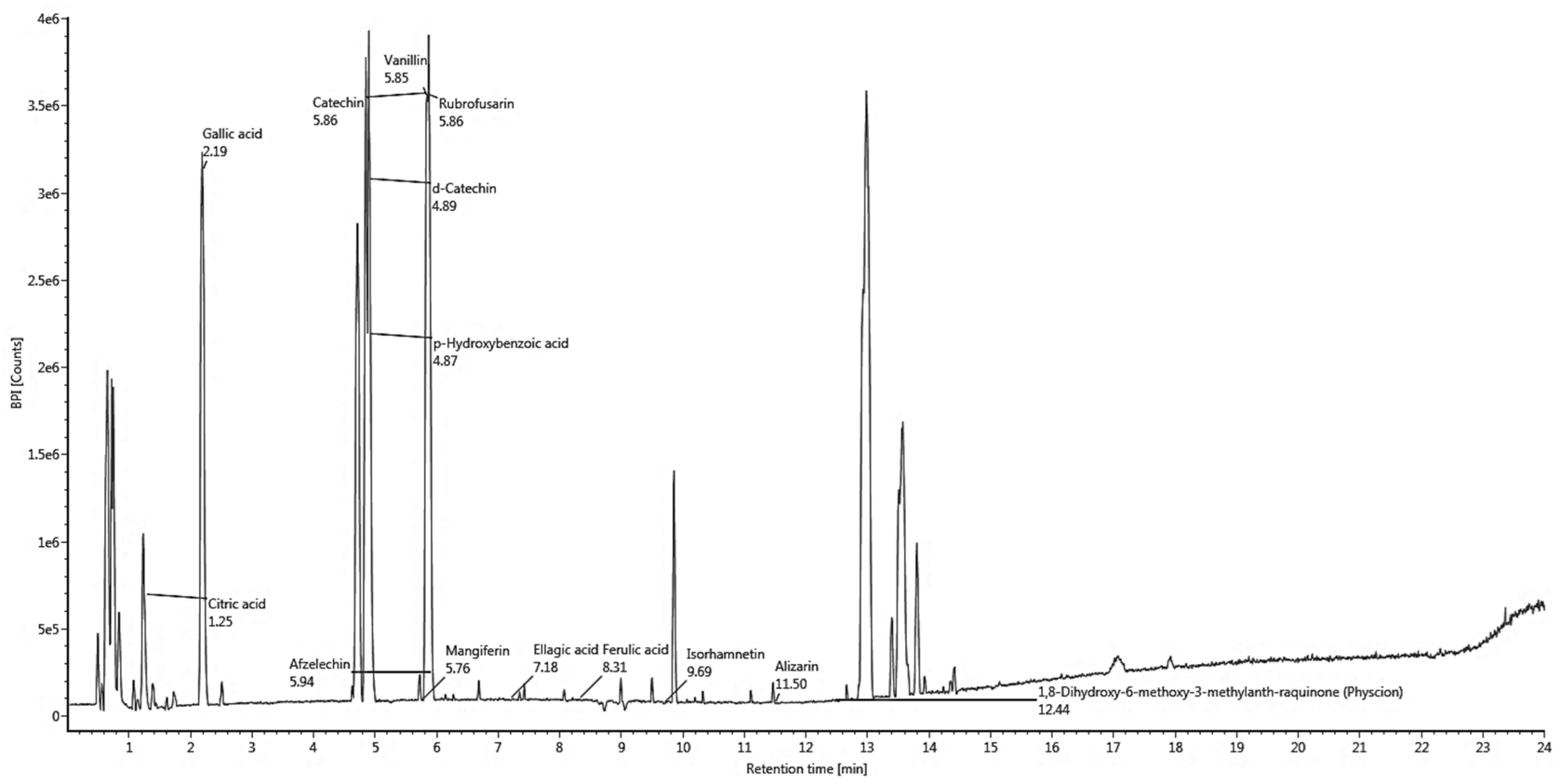

Figure 2 Phytochemical profiling of Divya-Kayakalp-Vati (DKV). Phytochemical composition of the DKV was identified using liquid chromatography-mass spectroscopy (LC-MS) QToF analysis in (A) positive mode, and (B) negative mode, based on their mass-to-charge ratio and retention time (min). Details of the phytochemicals identified in positive and negative mode are given in Table 2.

Total lesion score analysis in the OXA-stimulated mice showed a steep $(9.50 \pm 1.30$ folds $)$ and significant $(\mathrm{p}$-value $<0.01)$ increase compared to the control animals (Figure 7A). Individual lesion score analysis in the OXA-stimulated mice showed a significant increase for epidermal hyperplasia ( $2.25 \pm 0.88$ folds), hyperkeratosis $(1.75 \pm 0.70$ folds $)$, and pustule formation ( $2.62 \pm 1.06$ folds), along with neutrophil influx ( $2.87 \pm 0.83$ folds) in the dermal region compared to NC mice (Figure $7 \mathrm{~A}-\mathrm{E})$. DKV-O treatment of the OXA-simulated mice significantly (p-value $<0.01)$ reduced the total lesion score $(4.37 \pm 1.76$ folds $)$ 
A

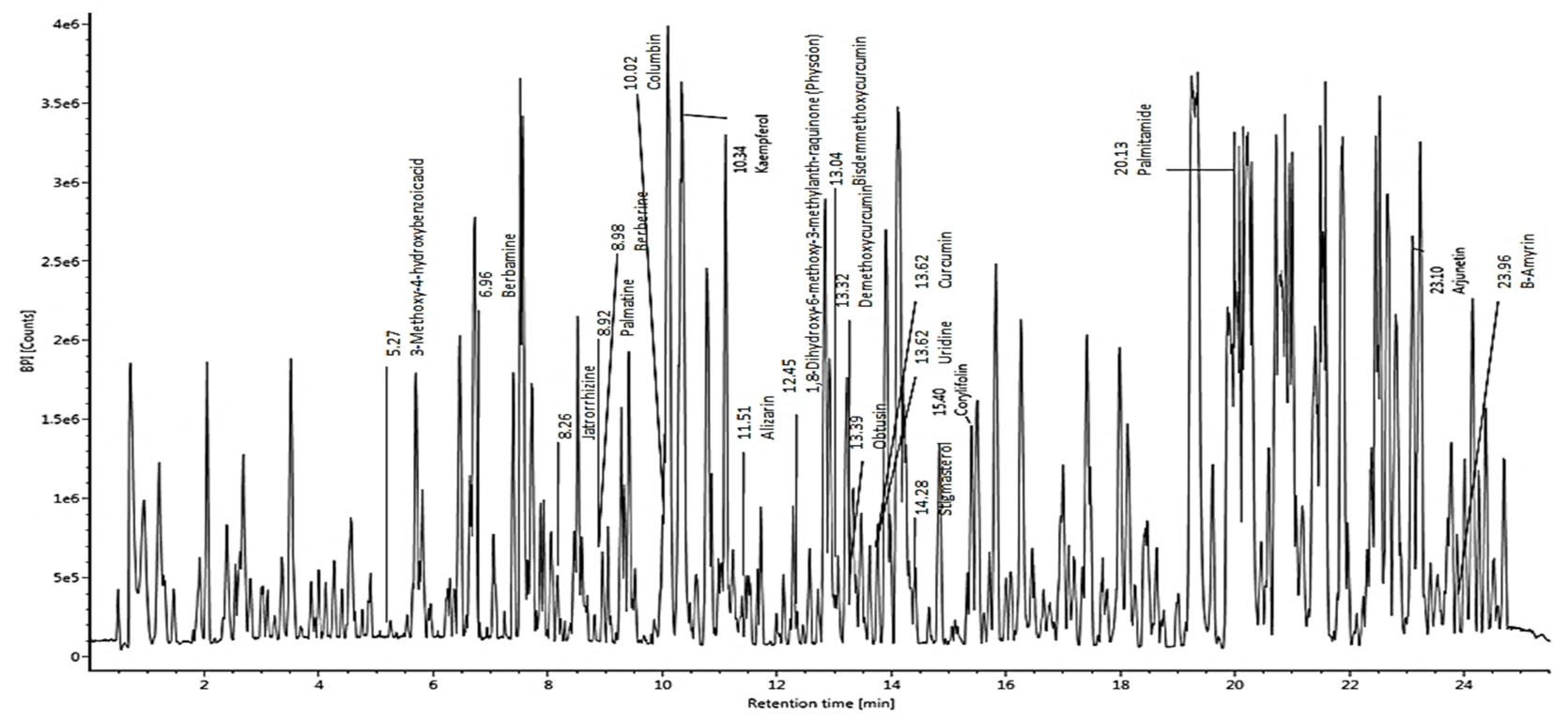

B

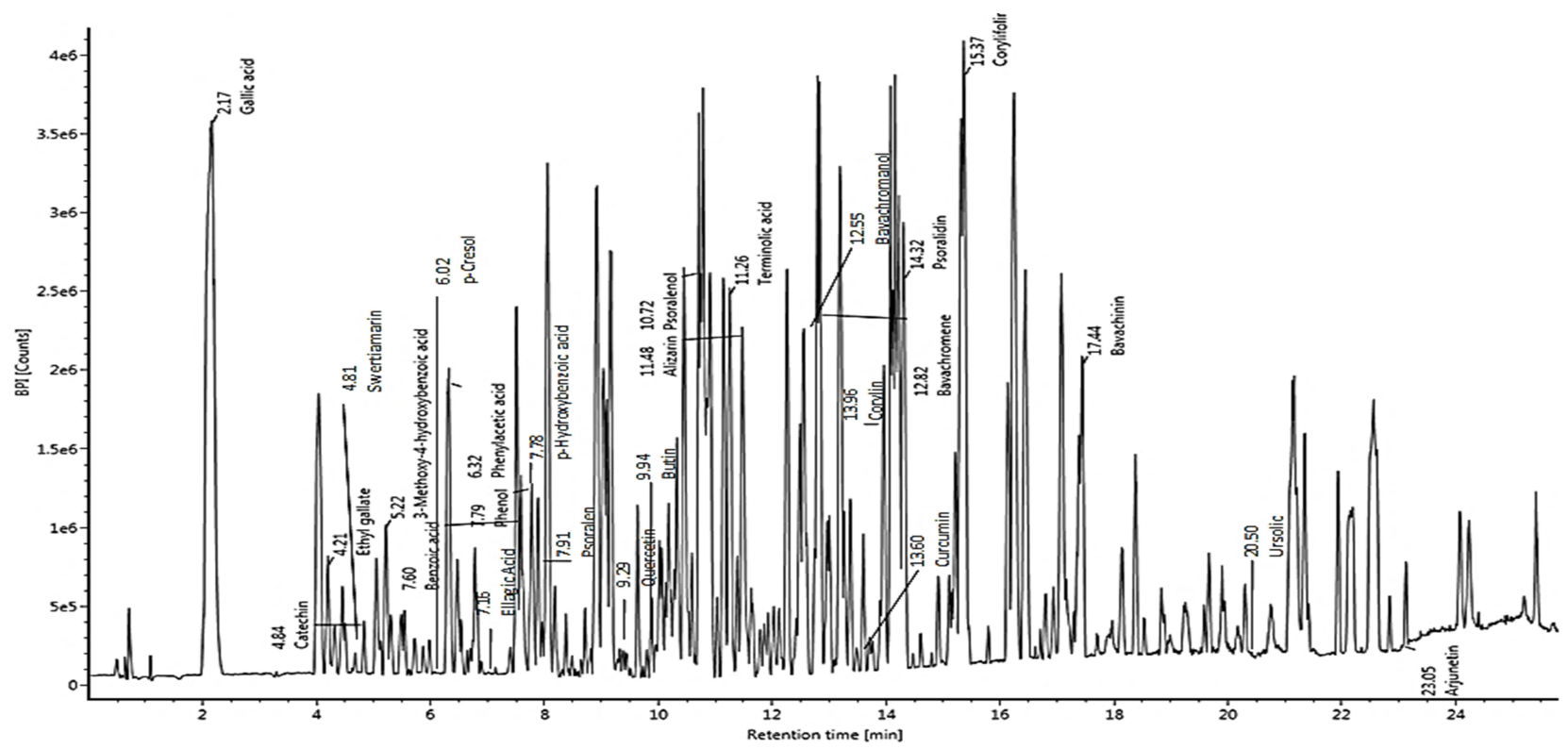

Figure 3 Phytochemical profiling of Divya-Kayakalp-Oil (DKO). Phytochemical composition of the DKO was identified using liquid chromatography-mass spectroscopy (LCMS) QToF analysis in (A) positive mode, and (B) negative mode, based on their mass-to-charge ratio and retention time (min). Details of the phytochemicals identified in positive and negative mode are given in. Table 2

(Figure 7A). Individual lesion scores in the DKV-O treated mice showed significant reduction (p-value $<0.01$ ) for epidermal hyperplasia ( $1.62 \pm 0.51$ folds), epidermal hyperkeratosis $(0.75 \pm 0.70$ folds), epidermal pustule formation $(0.37 \pm 0.74$ folds $)$ and neutrophil influx in dermis region $(1.5 \pm 0.53$ folds) (Figure 7B-E). DEXA treatment also showed significant (p-value $<0.01$ ) effects in reducing the OXA-stimulated total and individual inflammatory lesion scores (Figure 7A-E).

Induction of inflammation in the OXA-stimulated mice was analyzed through measurement of pro-inflammatory cytokines- interleukin (IL)- $1 \beta$, IL-6, and TNF- $\alpha$. In the blood serum of the DC animals stimulated with OXA 


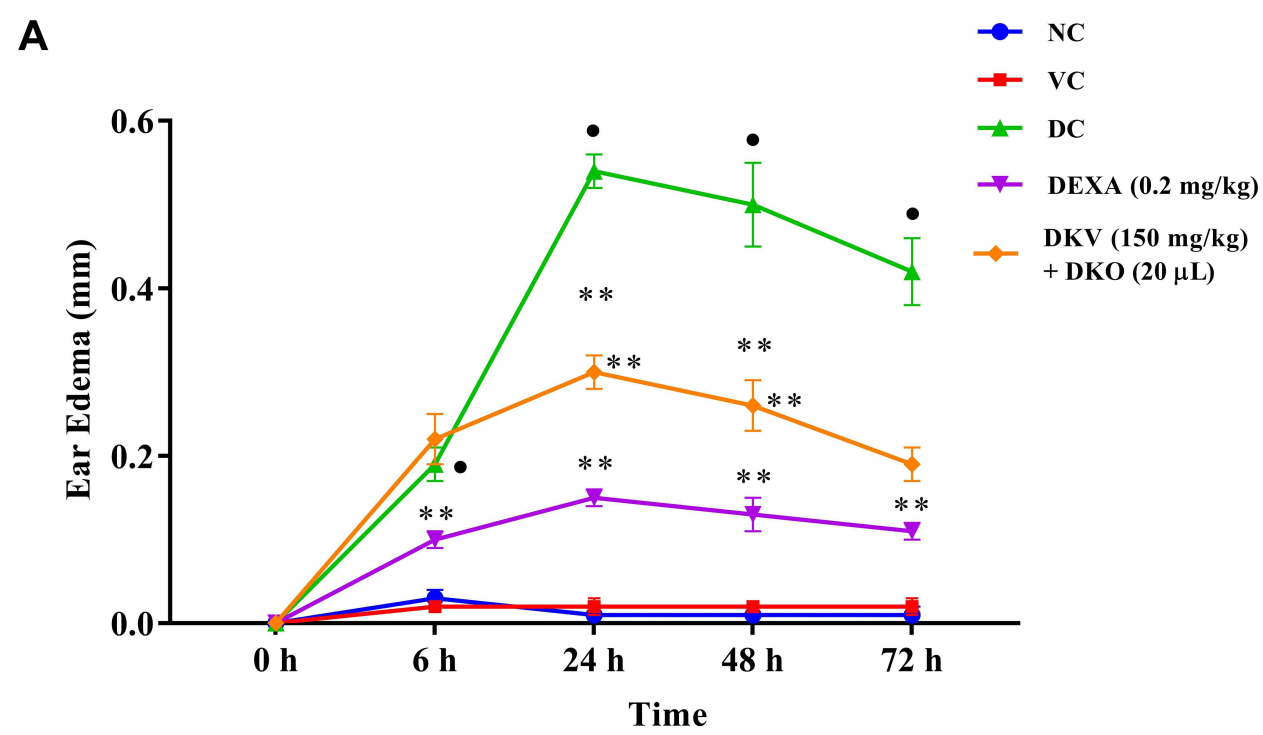

B

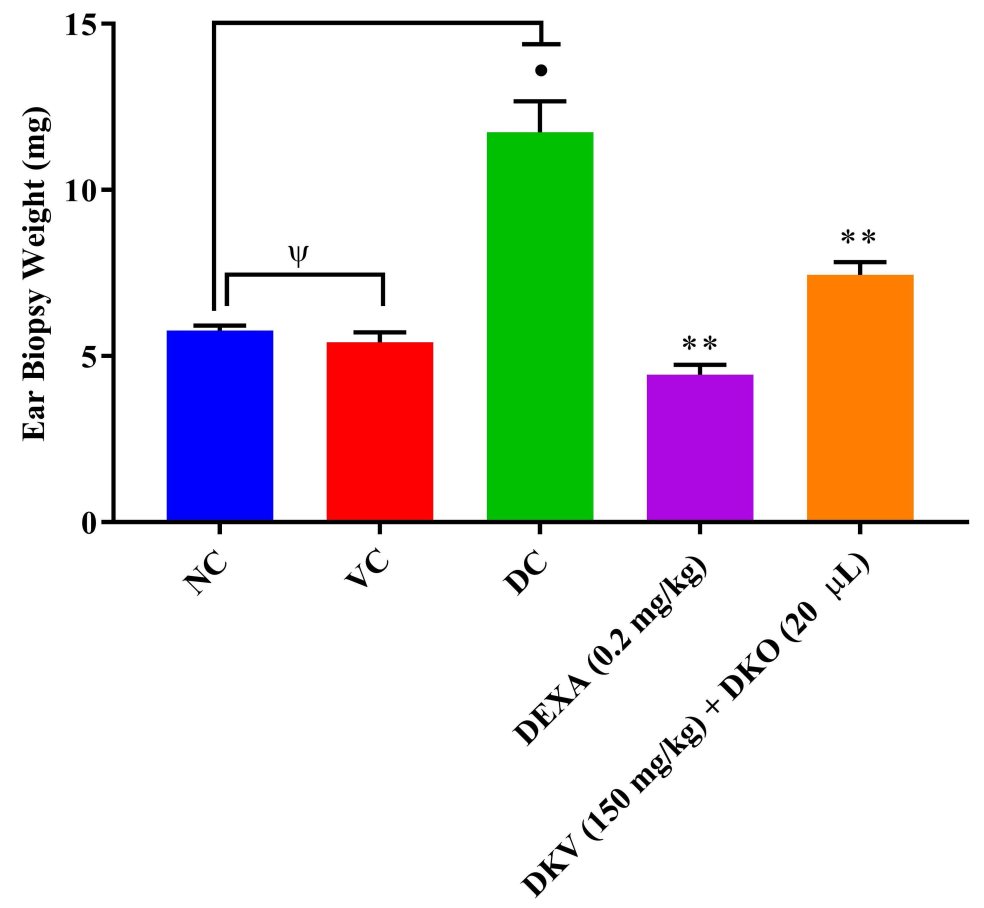

Figure 4 Ear edema and biopsy weight analysis in Oxazolone (OXA)-stimulated mice. Physiological parameters, such as (A) ear edema, and (B) ear biopsy weight changes were analyzed in I.5\% OXA-stimulated mice following co-treatment with Divya-Kayakalp-Vati ( $150 \mathrm{mg} / \mathrm{kg}$; P.O.) and Divya-Kayakalp-Oil (20 $\mu \mathrm{L}$, T.A.) (DKV-O), or treatment with Dexamethasone (DEXA; $0.2 \mathrm{mg} / \mathrm{kg}$; T.A.) alone. Acetone treatment was given as vehicle control (VC). $\mathrm{p}$-values $\bullet<0.0 \mathrm{l}$ (normal control (NC) versus disease control $(D C)$ ); ** <0.0I (DC versus DKV-O treatment; DC versus DEXA); $\Psi=$ Not significant.

a significant (p-value $<0.01)$ induction of IL-1 $\beta(5.27 \pm 0.66 \mathrm{pg} / \mathrm{mL})$, IL-6 $(18.87 \pm 6.25 \mathrm{pg} / \mathrm{mL}), \mathrm{TNF}-\alpha(8.84 \pm$ $2.01 \mathrm{pg} / \mathrm{mL}$ ) was observed (Figure 8A-C). Treatment with DKV-O significantly (p-value $<0.01$ ) reduced the presence of inflammatory cytokines in the blood serum of OXA-stimulated mice. The level of cytokines was determined at s IL-1ß: $3.21 \pm 1.00 \mathrm{pg} / \mathrm{mL}$, IL-6: $13.07 \pm 1.61 \mathrm{pg} / \mathrm{mL}$ and TNF- $\alpha: 7.1 \pm 0.81 \mathrm{pg} / \mathrm{mL}$ in the mice blood serum (Figure 8A-C). DEXA treatment of the OXA-stimulated mice also significantly (p-value $<0.01$ ) reduced the levels of pro-inflammatory cytokines to IL-1 $\beta: 2.44 \pm 0.58 \mathrm{pg} / \mathrm{mL}$, IL-6: $10.20 \pm 0.84 \mathrm{pg} / \mathrm{mL}$ and TNF- $\alpha$ : $4.55 \pm 0.29 \mathrm{pg} / \mathrm{mL}$ (Figure $8 \mathrm{~A}-\mathrm{C}$ ). Myeloperoxidase (MPO) is the most abundant protein produced by 
A

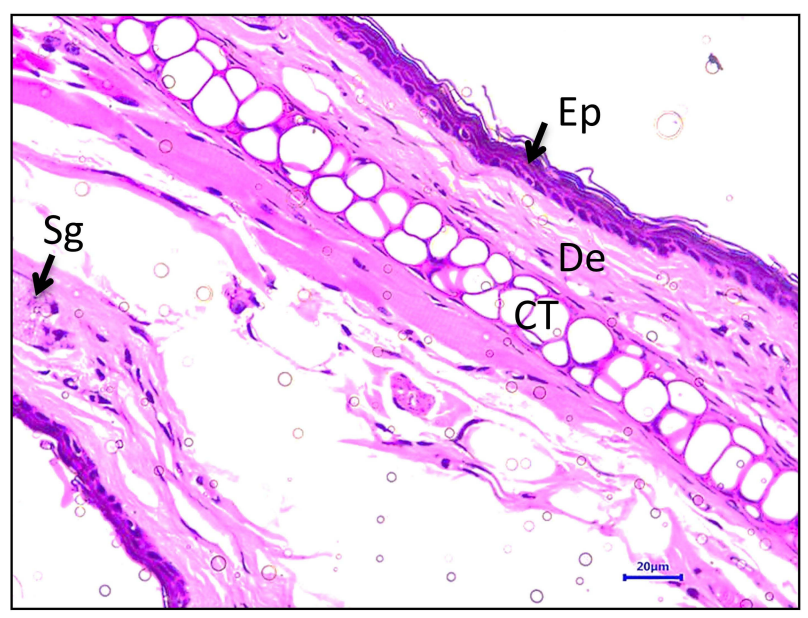

C

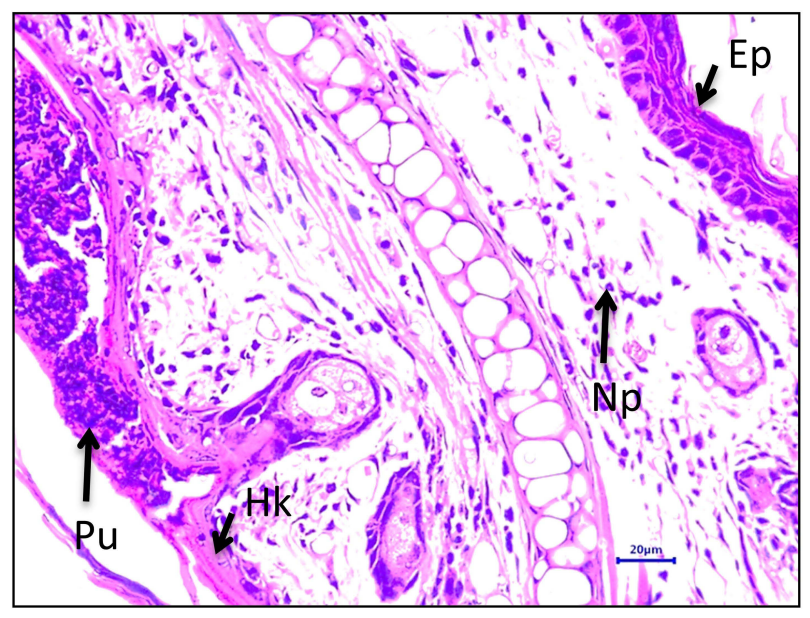

B

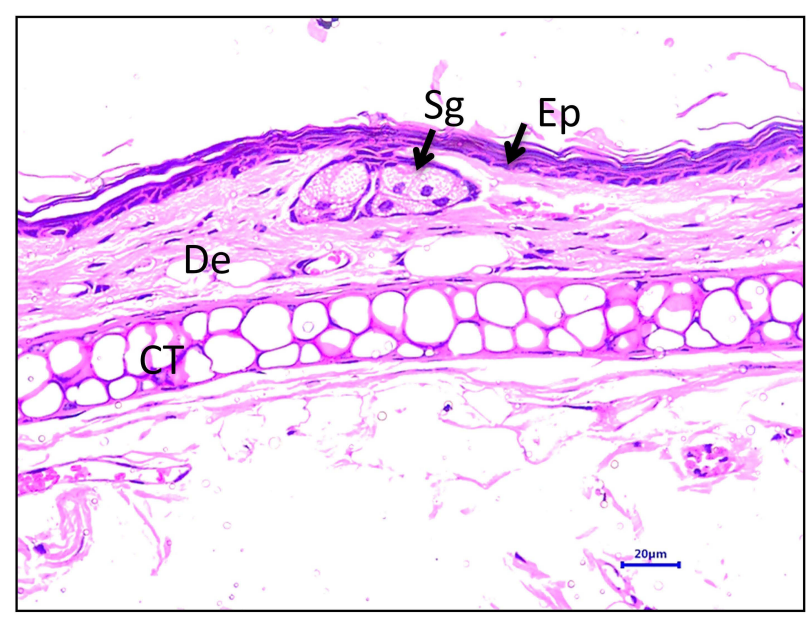

D

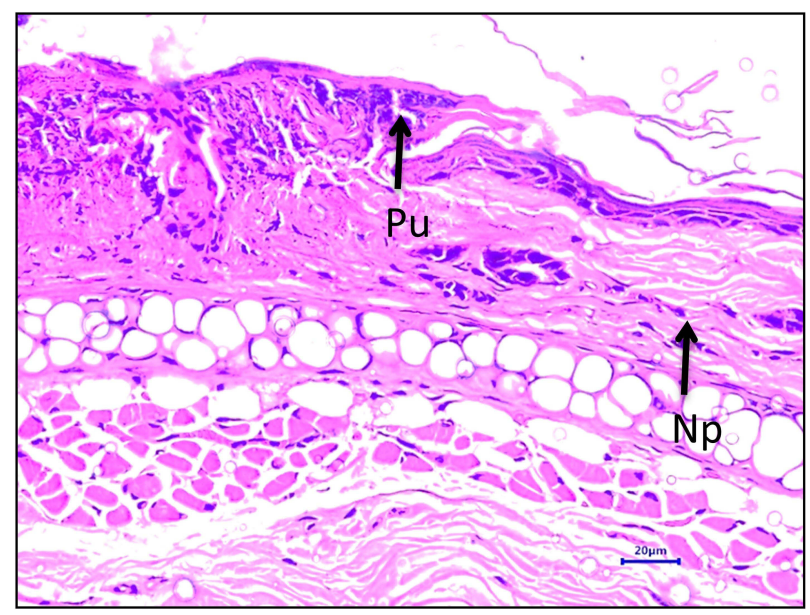

E

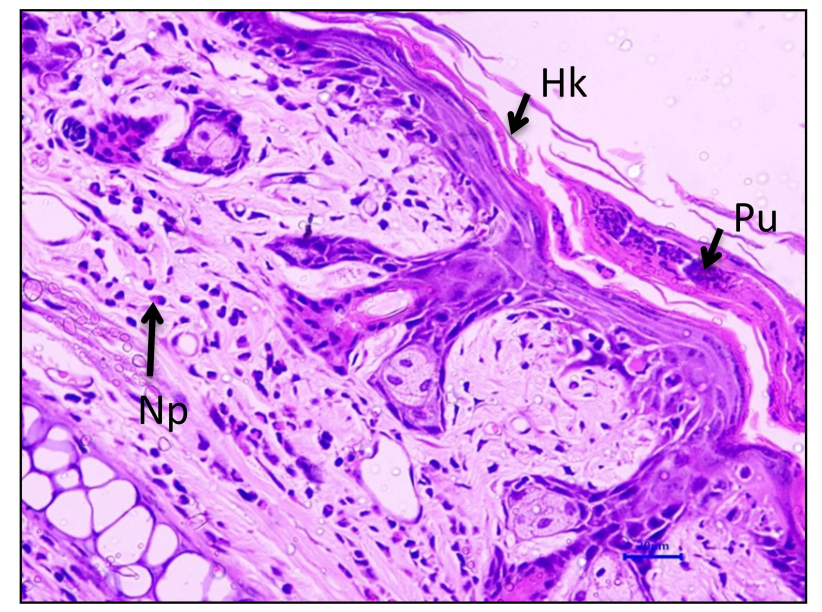

Figure 5 Histopathological analysis of ear tissue in Oxazolone (OXA)-stimulated mice. Histopathological images based lesion score (LS) analysis was performed in ear tissue obtained from (A) normal control (No OXA challenge) mice, (B) vehicle control (acetone) treated mice, (C) $1.5 \%$ OXA challenged DC mice, (D) 1.5\% OXA challenged mice treated with Dexamethasone (DEXA; $0.2 \mathrm{mg} / \mathrm{ear}$ ), and (E) I.5\% OXA challenged mice co-treated with DKV (150 mg/kg; P.O.) and DKO (20 $\mu \mathrm{L}$, T.A.). Tissue parts identified were epidermis $(\mathrm{EP})$, dermis $(\mathrm{De})$, sebaceous gland $(\mathrm{Sg})$, and cartilage $(\mathrm{CT})$ regions. Inflammatory lesions observed were hyperkeratosis (Hk), pustule formation $(\mathrm{Pu})$, and the influx of neutrophils $(\mathrm{Np})$. 


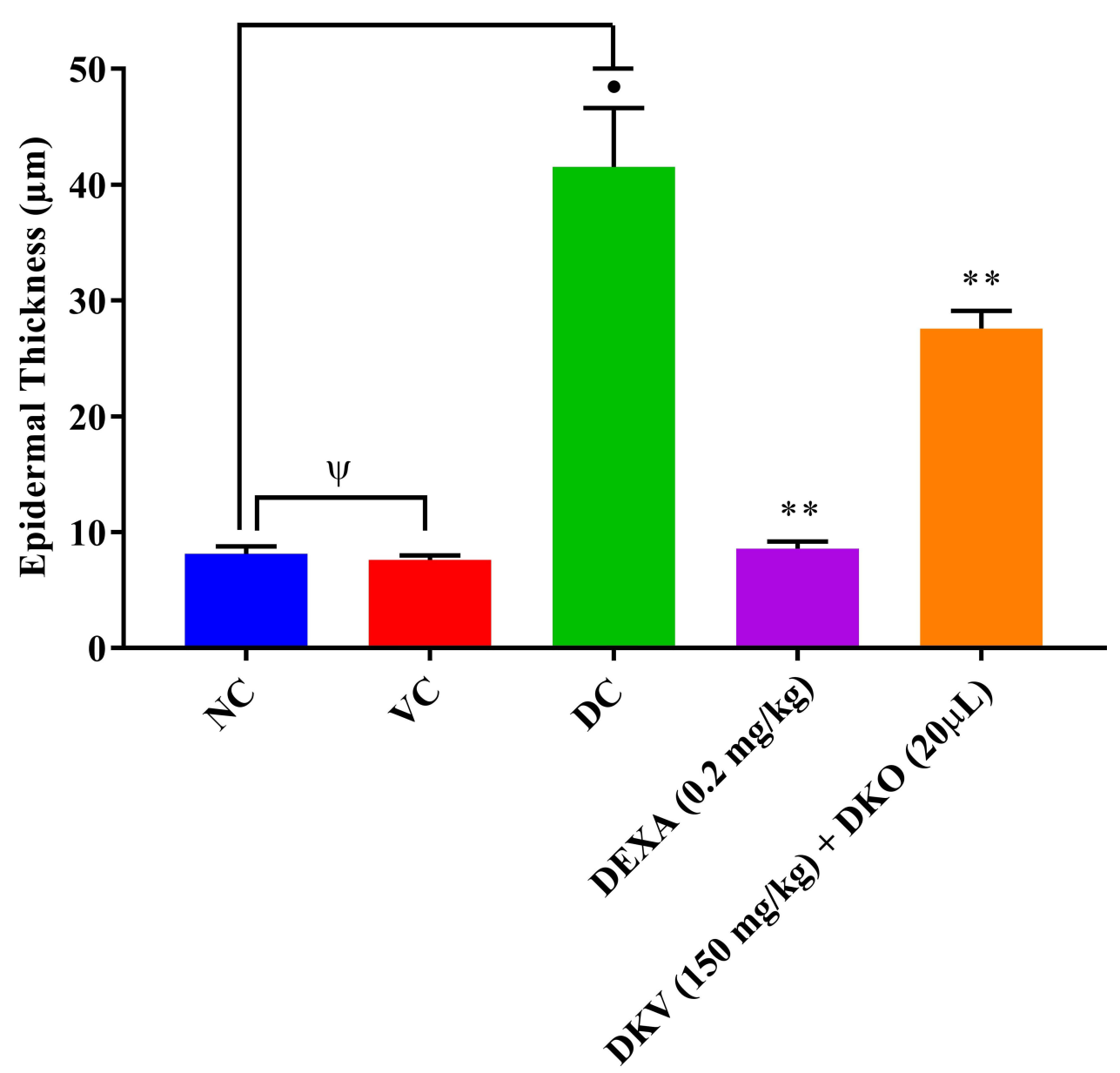

Figure 6 Ear epidermal thickness analysis in Oxazolone (OXA)-stimulated mice. Ear epidermal thickness was analyzed in 1.5\% OXA-stimulated mice following treatment with Divya-Kayakalp-Vati (150 mg/kg; P.O.) and Divya-Kayakalp-Oil (20 $\mu$ L, T.A.) (DKV-O) co-treatment, or Dexamethasone (DEXA; $0.2 \mathrm{mg} / \mathrm{kg})$ treatment. Acetone treatment was given as vehicle control (VC). Statistical analysis was performed using the one-way analysis of variance (ANOVA) method followed by Dunnett's multiple comparison $t$-test. p-values $\bullet<0.01$ (normal control (NC) versus disease control $(D C)$ ); $* * 0.01$ (DC versus DKV-O treatment; DC versus DEXA); $\Psi=$ Not significant.

neutrophilic granulocytes. In the present study, MPO was significantly (p-value $<0.001$ ) elevated in the OXA-treated mouse-ear $(5.38 \pm 1.12 \mathrm{U} / \mathrm{mg} \mathrm{fw})$ compared to NC mice MPO level $(1.34 \pm 0.61 \mathrm{U} / \mathrm{mg} \mathrm{fw})$ (Figure 8D). In the OXA-stimulated mice treated with DKV-O, the MPO level was found to be attenuated to $4.29 \pm 1.68 \mathrm{U} / \mathrm{mg} \mathrm{fw}$. DEXA treatment also significantly (p-value $<0.01)$ reduced the MPO levels $(1.67 \pm 0.67 \mathrm{U} / \mathrm{mg} \mathrm{fw}$ ) in the OXAstimulated mice ears compared to the DC animal (Figure 8D).

Thus, the combined treatment of DKV-O was observed to show potential anti-inflammatory and antioxidant potentials in the AD-like inflammation in mice. DKV-O effectively reduced the OXA-stimulated ear edema, lesion formations, and associated influx of inflammatory cells and soluble factors such as cytokines and myeloperoxidase. These antiinflammatory attributes for DKV-O could be related to the presence of phytochemicals in the poly-herbal formulations.

\section{Discussion}

Atopic Dermatitis (AD) is a common chronic relapsing inflammatory skin disease that is represented by the infiltration of the inflammatory cells and production of pro-inflammatory cytokines. ${ }^{36}$ The disease is often accompanied by the development of inflammatory skin lesions. AD has also been associated with an increased risk of developing other inflammatory diseases like arthritis, inflammatory bowel disease, and vitiligo. ${ }^{4,37}$ While, therapeutics for curing AD are directed towards immunomodulation with the objective of prevention and cure, the existence of endotypic disease complexity makes it difficult to exploit a final solution. Temporary relief from AD is acquired through anti-histamine and immunosuppressive agents, moisture care therapy, corticosteroids, or localized immuno-regulatory agents. ${ }^{38}$ However, 


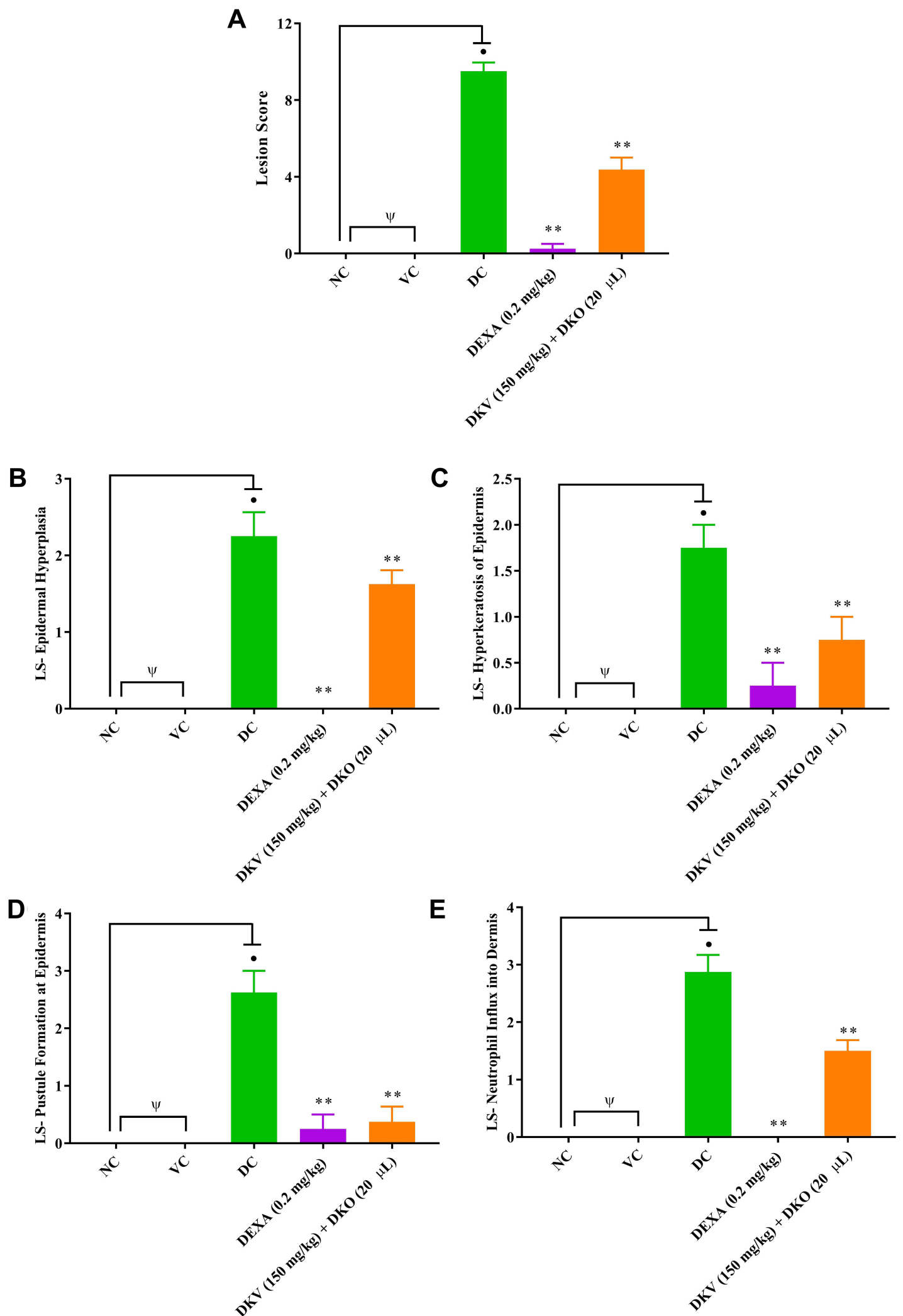

Figure 7 Inflammatory lesion score analysis in ear tissue obtained from Oxazolone (OXA)-stimulated mice. Histopathological lesion scoring (LS) was performed for (A) Total Lesion Score, (B) Epidermal hyperplasia, (C) Hyperkeratosis of the epidermis, (D) Pustule formation in the epidermis and (E) Neutrophil influx into the dermis in normal control (No OXA-challenge) mice, vehicle control (Acetone) treated mice, 1.5\% OXA challenged DC mice, 1.5\% OXA-challenged mice treated with Dexamethasone (DEXA; $0.2 \mathrm{mg} / \mathrm{ear}$ ), and $1.5 \%$ OXA challenged mice co-treated with DKV (150 mg/kg; P.O.) and DKO (20 $\mu \mathrm{L}$, T.A.). Statistical analysis was performed using one-way analysis of variance (ANOVA) followed by Dunnett's multiple comparison $t$-test was applied. p-value $\bullet \leq 0.01$ (normal control (NC) versus disease control (DC)). $* * 0.01$ (DC versus DKV-O treatment; DC versus DEXA); $\Psi=$ Not significant. 
A

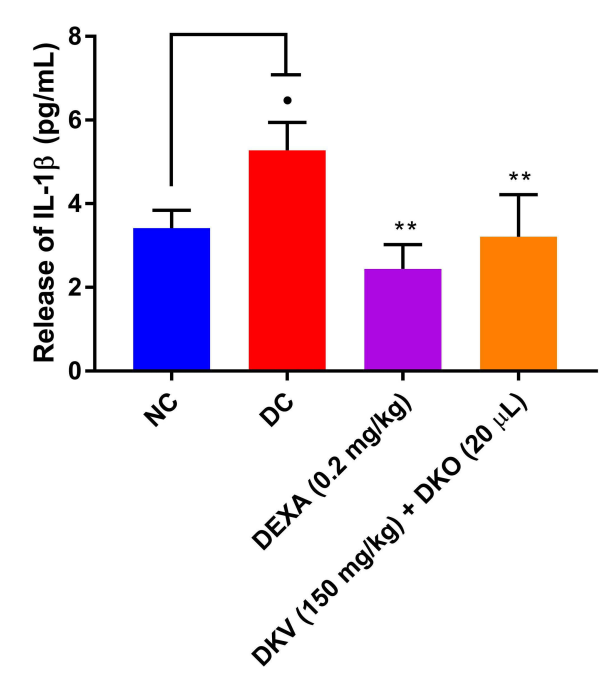

C

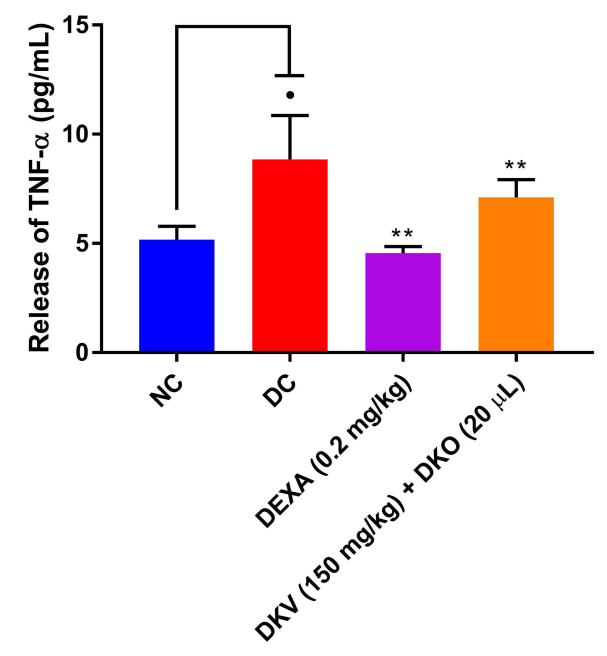

B

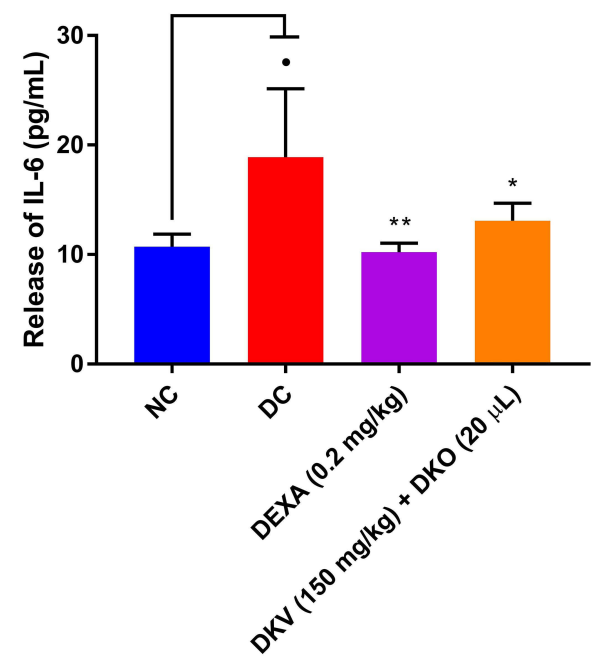

D

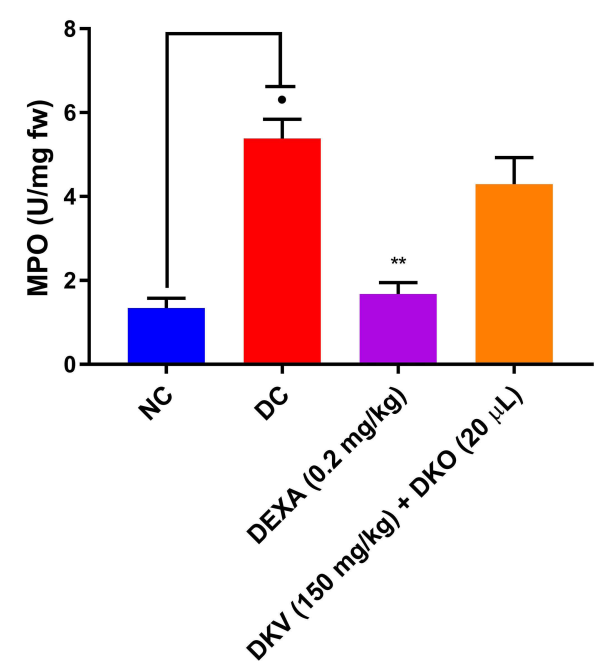

Figure 8 Inflammatory marker analysis in samples obtained from Oxazolone (OXA)-stimulated mice. Inflammatory markers- (A) Interleukin (IL)-I $\beta$, (B) IL-6, (C) tumor necrosis factor-alpha (TNF- $\alpha$ ) in the blood serum, and (D) myeloperoxidase (MPO) analysis was done in ear tissue stubs obtained from normal control (No OXA-challenge) mice, vehicle control (Acetone) treated mice, I.5\% OXA challenged DC mice, I.5\% OXA challenged mice treated with Dexamethasone (DEXA; 0.2 mg/ear), and I.5\% OXA challenged mice co-treated with DKV ( $150 \mathrm{mg} / \mathrm{kg}$; P.O.) and DKO (20 $\mu \mathrm{L}$, T.A.). Statistical analysis was performed using one-way analysis of variance (ANOVA) followed by Dunnett's multiple comparison $t$-test was applied. p-value $\bullet \leq 0.01$ (normal control (NC) versus disease control (DC)); ${ }^{*} \leq 0.05 * * \leq 0.01$ (DC versus DKV-O treatment; DC versus DEXA).

prolonged use of these medications can lead to other health-related side effects and drug intolerances. ${ }^{39}$ Phototherapy using UltraViolet radiation " $\mathrm{A}$ " (UVA) is not recommended for acute AD and other dermal inflammatory diseases like Psoriasis. ${ }^{40}$ Furthermore, UVA therapy can lead to photo-aging of skin and in some cases dermal carcinogenesis. ${ }^{40}$

Therefore, there is an increased necessity to discover more effective therapies against AD with minimum or no side effects. Medicinal plants play an important role in folk medicines with minimum side effects and some have been reported to have anti-AD applications. ${ }^{41-43}$ Tradition Indian medicine system is known as "Ayurveda" has been widely applied as an alternative or additive therapeutics. ${ }^{44} 46$ Herbal components of DKV-O such as Berberis aristata DC., Curcuma longa L., Caesalpinia bonducella F., Azadirachta indica A. Juss., Santalum album L., and Acacia catechu (L.F.) Willd. has shown efficacy in treating various dermal and non-dermal maladies. ${ }^{47-51}$ Therapeutic properties of the mono- and poly-herbal formulations have been attributed to their phytochemical contents including phenol, polyphenol, alkaloid, terpenoid, and glycoside classes of molecules. ${ }^{52}$ Phytochemicals identified in DKV-O have been reported to play a major role in regulating inflammation, prevention of allergen, and platelet-activating factors. ${ }^{53-56}$ Berbamine and Catechin attenuate the allergen-stimulated release 
of pro-inflammatory cytokines (IL-1 $\beta$, IL-6, and TNF- $\alpha$ ), the neutrophil influx into the affected site, and activation of NFkB, matrix metalloproteinase (MMP)-9, and acetylcholine esterase. ${ }^{57-61}$ Additionally, Berbamine exhibits anti-inflammatory activity through modulation of $\mathrm{T}$ cell activation and inhibition of NFKB and MAPK signaling pathways. ${ }^{34,35}$ Hence, the ADlike inflammation amelioration properties of DKV-O can be attributed to the reported immunomodulatory activity of these phytochemicals.

Activation of keratinocytes, inflammatory cells, and release of pro-inflammatory cytokines have been implicated as a major event in the induction of dermal inflammatory diseases like AD and psoriasis. Clinical studies have confirmed elevated levels of inflammatory cells along with the release of IL- $1 \beta$, IL-6, and TNF- $\alpha$ cytokines in the dermal tissues of $\mathrm{AD}$ and psoriasis patients. ${ }^{62,63} \mathrm{DKV}-\mathrm{O}$ treatment was found capable of altering the OXA-stimulated ear edema, and associated inflammation through the modulation of inflammatory cells influx into the dermis and release of proinflammatory cytokines. During AD, IL- $1 \beta$ and TNF- $\alpha$ are released by inflamed keratinocytes and activated immune cells. ${ }^{64}$ While serum IL-1 $\beta$ and TNF- $\alpha$ levels stimulate the release of IL-6 cytokines from T-cells. ${ }^{65,66}$ Phytochemicals contents of DKV-O such as Curcumin, Berberine, and Gallic Acid possess excellent anti-inflammatory, anti-oxidant, chemo-preventive, and chemotherapeutic activities. Curcumin modulates T-cell secretion of pro-inflammatory cytokines including TNF-alpha responsible for the induction of inflammation and epidermal edema. ${ }^{67,68}$ Similarly, Gallic acid and Berberine are responsible for inhibiting allergen stimulated release of pro-inflammatory cytokine release from macrophages and in reducing induced epidermal edema. ${ }^{69}$

Myeloperoxidase (MPO) is a well-known biomarker for skin inflammation originating from stimulated neutrophilic granulocytes. ${ }^{70}$ In the present study, DKV-O treatment reduced the OXA-stimulated MPO levels in the inflamed ear tissue of mice directly indicating a reduced presence of activated neutrophils. Histopathological analysis confirmed the reduced influx of neutrophils in the DKV-O treated inflamed ear tissue dermis along with a moderated generation of inflammatory lesions such as hyperkeratosis, hyperplasticity, and pustule formation in the epidermis. The results correlate well with our previous finding showing DKV-O eliminated 12-O-tetradecanoyl phorbol 13-acetate (TPA) stimulated inflammatory lesion and the neutrophil influx into the dermal region. ${ }^{27}$ 1.8-Dihydroxy-3-methylanthraquinone (Chrysophanol) is known as a multifaceted phytochemical that has anti-inflammatory, anti-cancer, hepatoprotective, and neuroprotective activities. ${ }^{71}$ Pretreatment of human mast cells (HMC-1) with Chrysophanol suppressed intracellular calcium levels and histamine release following phorbol 12-myristate 13-acetate and calcium ionophore treatments. ${ }^{72}$ Chrysophanol also reduced the overexpression of caspase-1, nuclear factor- $\mathrm{KB}$, and thymic stromal lymphopoietin in the stimulated HMC-1 cells. ${ }^{72}$ In human keratinocytes (HaCaT cells) pretreatment with chrysophanol significantly reduced stimulated expression of caspase-1 and thymic stromal lymphopoietin proteins. ${ }^{72}$ Similarly, Quercetin is a flavonoid that has been observed to inhibit neutrophil influx in affected regions during the onset of rheumatoid arthritis. ${ }^{73}$ In addition, Quercetin leads the neutrophils to undergo apoptosis, reducing the incidences of neutrophilic extracellular trap formation and release of extracellular pro-inflammatory cytokines. ${ }^{73}$ Additionally, Quercetin pre-treatment reduced oxidative stress through the generation of antioxidants within the in vitro model for AD using HaCaT cells treated with IL-4, IL-13, and TNF- $\alpha .{ }^{74}$ Quercetin also increased the mRNA expression of occludin and E-cadherin, while downregulating MMP1, MMP2, and MMP9 expression stimulating wound healing in stimulated HaCaT cells as well as, downregulated phosphorylation of MAPK, and NF- $\mathrm{KB}$ reducing inflammation. ${ }^{74}$

In the end, phytochemical constituents of the DKV-O are extensively responsible for the inhibition of inflammation through the modulation of the activated immune cells and the release of the pro-inflammatory cytokines. Though further analysis is still required for understanding the individual contribution of the herbal components and phytochemicals present in the DKV-O. It is important to note that the current study demonstrated the efficacy of DKV-O as a whole, where its herbal components functioned in synergy, and possibly in a multifocal manner in moderating the acute inflammation triggered by OXA. Also, species-wise variations exist for biological studies, due to which caution needs to be taken while translating the observed efficacy of DKV-O in mice to humans.

\section{Conclusion}

In short, combined treatment of DKV-O showed anti-inflammatory efficacy in ameliorating stimulated AD through the modulation of inflammatory neutrophilic influx, and release of pro-inflammatory cytokines. Suppression of inflammation in 
the OXA-stimulated ear tissue also lessened the incidence of inflammatory lesion generation. The observed anti-AD efficacy of the DKV-O can be attributed to the rich presence of all the phytochemicals working in synergy. These phytochemicals directly function in reducing inflammation by modulating the inflammatory cells and activated keratinocytes and their multicentric synergistic effect in the modulation of AD-like inflammatory response needs further exploration. Taken together, DKV-O could well be a suitable healing option for atopic dermatitis-like inflammatory skin diseases.

\section{Abbreviations}

AD, Atopic Dermatitis; IL-1 $\beta$, Interleukin-1 beta; IL-6, Interleukin-6; TNF- $\alpha$, Tumor necrosis factor-alpha; MPO, Myeloperoxidase; ELISA, Enzyme-Linked Immunosorbent Assay; DC, disease control; DKV, Divya-Kayakalp-Vati; DKO, Divya-Kayakalp-Oil; DKV-O, Divya-Kayakalp-Vati and Divya-Kayakalp-Oil co-treatment; DEXA, Dexamethasone; OXA, Oxazolone; CPCSEA, Committee for the Purpose of Control and Supervision of Experiments on Animals; IAEC, Institutional Animal Ethical Committee, ICH, International Conference on Harmonization; Na-CMC, Sodium-carboxymethyl cellulose, ANOVA, One-way analysis of variance; NC, normal control; LC-MS QToF, Liquid Chromatography-Mass Spectroscopy Quadrupole Time-of-Flight; Th2, T helper-2; IgE, Immunoglobulin E; T.A., Topical application; P.O., per os (orally); H\&E stain, Haematoxylin and Eosin stain; TMB, 3,3',5,5'-tetramethylbenzidine; m/z, Mass-charge ratio; UVA, UltraVoilet radiation "A"; NFкB, Nuclear factor kappa B; MAPK, Mitogen-activated protein kinase; TPA, 12-O-tetradecanoyl phorbol 13-acetate; HMC-1, Human mast cells; HaCaT, Human Keratinocyte cells; mRNA, Messenger ribonucleic acid.

\section{Acknowledgments}

We thank Mr. Hoshiyar Singh and Dr. Niti Sharma for their support in conducting biochemical assays. We would also like to appreciate Mr. Bhanu Pratap, Mr. Pushpendra Singh, Mr. Vipin Kumar, and Mr. Sonit Kumar for the excellent animal handling and maintenance support. We extend our gratitude to Mr. Brij Kishore, Mr. Pardeep Nain, Mr. Tarun Rajput, Mr. Gagan Kumar, and Mr. Lalit Mohan for their swift administrative support. This research work was funded internally by Patanjali Research Foundation Trust, Haridwar, India.

\section{Disclosure}

The test articles were sourced from Divya Pharmacy, Haridwar, Uttarakhand, India. Acharya Balkrishna is an honorary trustee in Divya Yog Mandir Trust, Haridwar, India; in addition, he holds an honorary managerial position in Patanjali Ayurved Ltd., Haridwar, India; he reports no other potential conflicts of interest for this work. Besides, providing the test article, Divya Pharmacy was not involved in any aspect of this study. All other authors report no conflicts of interest for this work.

\section{References}

1. Cork MJ, Thaci D, Eichenfield LF, et al. Dupilumab provides favourable long-term safety and efficacy in children aged $>/=6$ to $<12$ years with uncontrolled severe atopic dermatitis: results from an open-label phase IIa study and subsequent Phase III open-label extension study. $\mathrm{Br}$ J Dermatol. 2021;184(5):857-870. doi:10.1111/bjd.19460

2. Paller AS, Siegfried EC, Thaci D, et al. Efficacy and safety of dupilumab with concomitant topical corticosteroids in children 6 to 11 years old with severe atopic dermatitis: a randomized, double-blinded, placebo-controlled Phase 3 trial. J Am Acad Dermatol. 2020;83(5):1282-1293. doi:10.1016/j.jaad.2020.06.054

3. Lin YT, Wang CT, Chiang BL. Role of bacterial pathogens in atopic dermatitis. Clin Rev Allergy Immunol. 2007;33(3):167-177. doi:10.1007/ s12016-007-0044-5

4. Weidinger S, Beck LA, Bieber T, Kabashima K, Irvine AD. Atopic dermatitis. Nat Rev Dis Primers. 2018;4(1):1. doi:10.1038/s41572-018-0001-z

5. Jin H, He R, Oyoshi M, Geha RS. Animal models of atopic dermatitis. J Invest Dermatol. 2009;129(1):31-40. doi:10.1038/jid.2008.106

6. Maarouf M, Vaughn AR, Shi VY. Topical micronutrients in atopic dermatitis-An evidence-based review. Dermatol Ther. 2018;31(5):e12659. doi:10.1111/dth. 12659

7. Leung DY, Boguniewicz M, Howell MD, Nomura I, Hamid QA. New insights into atopic dermatitis. J Clin Invest. 2004;113(5):651-657. doi:10.1172/JCI21060

8. Longo G, Berti I, Burks AW, Krauss B, Barbi E. IgE-mediated food allergy in children. Lancet. 2013;382(9905):1656-1664. doi:10.1016/S01406736(13)60309-8

9. van der Hulst AE, Klip H, Brand PL. Risk of developing asthma in young children with atopic eczema: a systematic review. $J$ Allergy Clin Immunol. 2007;120(3):565-569. doi:10.1016/j.jaci.2007.05.042

10. Kapoor R, Menon C, Hoffstad O, Bilker W, Leclerc P, Margolis DJ. The prevalence of atopic triad in children with physician-confirmed atopic dermatitis. J Am Acad Dermatol. 2008;58(1):68-73. doi:10.1016/j.jaad.2007.06.041 
11. Irvine AD, McLean WH, Leung DY. Filaggrin mutations associated with skin and allergic diseases. $N$ Engl J Med. 2011;365(14):1315-1327. doi:10.1056/NEJMra1011040

12. Ellinghaus D, Baurecht H, Esparza-Gordillo J, et al. High-density genotyping study identifies four new susceptibility loci for atopic dermatitis. Nat Genet. 2013;45(7):808-812. doi:10.1038/ng.2642

13. Palmer CN, Irvine AD, Terron-Kwiatkowski A, et al. Common loss-of-function variants of the epidermal barrier protein filaggrin are a major predisposing factor for atopic dermatitis. Nat Genet. 2006;38(4):441-446. doi:10.1038/ng1767

14. Nettis E, Ortoncelli M, Pellacani G, et al. A multicenter study on the prevalence of clinical patterns and clinical phenotypes in adult atopic dermatitis. J Investig Allergol Clin Immunol. 2020;30(6):448-450. doi:10.18176/jiaci.0519

15. Tavakolpour S. Tofacitinib as the potent treatment for refractory pemphigus: a possible alternative treatment for pemphigus. Dermatol Ther. 2018;31(5):e12696. doi:10.1111/dth.12696

16. Brunner PM, Khattri S, Garcet S, et al. A mild topical steroid leads to progressive anti-inflammatory effects in the skin of patients with moderate-to-severe atopic dermatitis. J Allergy Clin Immunol. 2016;138(1):169-178. doi:10.1016/j.jaci.2015.12.1323

17. Danby SG, Chittock J, Brown K, Albenali LH, Cork MJ. The effect of tacrolimus compared with betamethasone valerate on the skin barrier in volunteers with quiescent atopic dermatitis. Br J Dermatol. 2014;170(4):914-921. doi:10.1111/bjd.12778

18. Nakahara T, Morimoto H, Murakami N, Furue M. Mechanistic insights into topical tacrolimus for the treatment of atopic dermatitis. Pediatr Allergy Immunol. 2018;29(3):233-238. doi:10.1111/pai.12842

19. Jensen JM, Weppner M, Dahnhardt-Pfeiffer S, et al. Effects of pimecrolimus compared with triamcinolone acetonide cream on skin barrier structure in atopic dermatitis: a randomized, double-blind, right-left arm trial. Acta Derm Venereol. 2013;93(5):515-519. doi:10.2340/00015555-1533

20. Zebda R, Paller AS. Phosphodiesterase 4 inhibitors. J Am Acad Dermatol. 2018;78(3 Suppl 1):S43-S52. doi:10.1016/j.jaad.2017.11.056

21. Garritsen FM, Brouwer MW, Limpens J, Spuls PI. Photo(chemo)therapy in the management of atopic dermatitis: an updated systematic review with implications for practice and research. Br J Dermatol. 2014;170(3):501-513. doi:10.1111/bjd.12645

22. Dattola A, Bennardo L, Silvestri M, Nistico SP. What's new in the treatment of atopic dermatitis? Dermatol Ther. 2019;32(2):e12787. doi:10.1111/ dth. 12787

23. Castela E, Archier E, Devaux S, et al. Topical corticosteroids in plaque psoriasis: a systematic review of risk of adrenal axis suppression and skin atrophy. J Eur Acad Dermatol Venereol. 2012;26(Suppl 3):47-51. doi:10.1111/j.1468-3083.2012.04523.x

24. AFI. Ayurvedic Formulary of India, Part 12 ed. Delhi; 2003.

25. UPI. The Unani Pharmacopia of India Ministry of AYUSH. Government of India; 2007.

26. Trikamji J. Charaka Samhita of Agnivesha, Chikitsa Sthana; Abhaya Amalaki Rasayana Pada. Vol 1. 1 ed. Varanasi: Chowkhambha Prakashan; 2007:378-379.

27. Balkrishna A, Sakat SS, Joshi K, et al. Modulation of psoriatic-like skin inflammation by traditional Indian medicine Divya-Kayakalp-Vati and Oil through attenuation of pro-inflammatory cytokines. J Tradit Complement Med. 2021. doi:10.1016/j.jtcme.2021.09.003

28. Man MQ, Hatano Y, Lee SH, et al. Characterization of a hapten-induced, murine model with multiple features of atopic dermatitis: structural, immunologic, and biochemical changes following single versus multiple oxazolone challenges. J Invest Dermatol. 2008;128(1):79-86. doi:10.1038/ sj.jid. 5701011

29. CPCSEA. Committee for the Purpose of Control and Supervision of Experiments on Animals (CPCSEA). Compendium of CPCSEA; 2018.

30. Percie du Sert N, Ahluwalia A, Alam S, et al. Reporting animal research: explanation and elaboration for the ARRIVE guidelines 2.0. PLoS Biol. 2020;18(7):e3000411. doi:10.1371/journal.pbio.3000411

31. Webb EF, Tzimas MN, Newsholme SJ, Griswold DE. Intralesional cytokines in chronic oxazolone-induced contact sensitivity suggest roles for tumor necrosis factor alpha and interleukin-4. J Invest Dermatol. 1998;111(1):86-92. doi:10.1046/j.1523-1747.1998.00239.x

32. Suzuki K, Ota H, Sasagawa S, Sakatani T, Fujikura T. Assay method for myeloperoxidase in human polymorphonuclear leukocytes. Anal Biochem. 1983;132(2):345-352. doi:10.1016/0003-2697(83)90019-2

33. Moon PD, Han NR, Lee JS, et al. Use of physcion to improve atopic dermatitis-like skin lesions through blocking of thymic stromal lymphopoietin. Molecules. 2019;24:8. doi:10.3390/molecules24081484

34. Jia XJ, Li X, Wang F, Liu HQ, Zhang DJ, Chen Y. Berbamine exerts anti-inflammatory effects via inhibition of NF-kappaB and MAPK signaling pathways. Cell Physiol Biochem. 2017;41(6):2307-2318. doi:10.1159/000475650

35. Luo CN, Lin X, Li WK, et al. Effect of berbamine on T-cell mediated immunity and the prevention of rejection on skin transplants in mice. J Ethnopharmacol. 1998;59(3):211-215. doi:10.1016/S0378-8741(97)00117-7

36. Nakagawa R, Yoshida H, Asakawa M, et al. Pyridone 6, a pan-JAK inhibitor, ameliorates allergic skin inflammation of NC/Nga mice via suppression of Th2 and enhancement of Th17. J Immunol. 2011;187(9):4611-4620. doi:10.4049/jimmunol.1100649

37. Acharya P, Mathur M. Association of atopic dermatitis with vitiligo: a systematic review and meta-analysis. J Cosmet Dermatol. 2020;19 (8):2016-2020. doi:10.1111/jocd.13263

38. Kim JE, Lee YB, Lee JH, et al. Disease awareness and management behavior of patients with atopic dermatitis: a questionnaire survey of 313 patients. Ann Dermatol. 2015;27(1):40-47. doi:10.5021/ad.2015.27.1.40

39. Yang H, Jung EM, Ahn C, et al. Elemol from Chamaecyparis obtusa ameliorates 2,4-dinitrochlorobenzene-induced atopic dermatitis. Int J Mol Med. 2015;36(2):463-472. doi:10.3892/ijmm.2015.2228

40. Megna M, Napolitano M, Patruno C, et al. Systemic treatment of adult atopic dermatitis: a review. Dermatol Ther. 2017;7(1):1-23. doi:10.1007/ s13555-016-0170-1

41. Karimi A, Majlesi M, Rafieian-Kopaei M. Herbal versus synthetic drugs; beliefs and facts. J Nephropharmacol. 2015;4(1):27-30.

42. Joo SS, Yoo YM, Ko SH, et al. Effects of essential oil from Chamaecypris obtusa on the development of atopic dermatitis-like skin lesions and the suppression of Th cytokines. J Dermatol Sci. 2010;60(2):122-125. doi:10.1016/j.jdermsci.2010.08.008

43. Chen Y, Xian Y, Lai Z, Loo S, Chan WY, Lin ZX. Anti-inflammatory and anti-allergic effects and underlying mechanisms of Huang-Lian-Jie-Du extract: implication for atopic dermatitis treatment. $J$ Ethnopharmacol. 2016;185:41-52. doi:10.1016/j.jep.2016.03.028

44. Ravishankar B, Shukla VJ. Indian systems of medicine: a brief profile. Afr J Tradit Complement Altern Med. 2007;4(3):319-337. doi:10.4314/ ajtcam.v4i3.31226

45. Balkrishna A, Sakat SS, Joshi K, et al. Herbo-mineral formulation 'Ashwashila' attenuates rheumatoid arthritis symptoms in collagen-antibodyinduced arthritis (CAIA) mice model. Sci Rep. 2019;9(1):8025. doi:10.1038/s41598-019-44485-9 
46. Balkrishna A, Sakat SS, Joshi K, et al. Anti-Inflammatory and anti-arthritic efficacies of an Indian traditional herbo-mineral medicine "Divya Amvatari Ras" in Collagen Antibody-Induced Arthritis (CAIA) mouse model through modulation of IL-6/IL-1beta/TNF-alpha/NFkappaB signaling. Front Pharmacol. 2019;10:659. doi:10.3389/fphar.2019.00659

47. Kumar R, Gupta YK, Singh S. Anti-inflammatory and anti-granuloma activity of Berberis aristata DC. in experimental models of inflammation. Indian J Pharmacol. 2016;48(2):155-161. doi:10.4103/0253-7613.178831

48. Shukla S, Mehta A. In vivo anti-inflammatory, analgesic and antipyretic activities of a medicinal plant, Caesalpinia bonducella F. Pak J Pharm Sci. 2015;28(4 Suppl):1517-1521.

49. Umar MI, Asmawi MZ, Sadikun A, et al. Multi-constituent synergism is responsible for anti-inflammatory effect of Azadirachta indica leaf extract. Pharm Biol. 2014;52(11):1411-1422. doi:10.3109/13880209.2014.895017

50. Moy RL, Levenson C. Sandalwood album oil as a botanical therapeutic in dermatology. J Clin Aesthet Dermatol. 2017;10(10):34-39.

51. Vaughn AR, Branum A, Sivamani RK. Effects of Turmeric (Curcuma longa) on skin health: a systematic review of the clinical evidence. Phytother Res. 2016;30(8):1243-1264. doi:10.1002/ptr.5640

52. Borokini TI, Omotayo FO. Phytochemical and ethnobotanical study of some selected medicinal plants from Nigeria. J Med Plants Res. 2012;6 (7):1106-1118.

53. Kroes BH, van den Berg AJ, Quarles van Ufford HC, van Dijk H, Labadie RP. Anti-inflammatory activity of gallic acid. Planta Med. 1992;58 (6):499-504. doi:10.1055/s-2006-961535

54. Kuo CL, Chi CW, Liu TY. The anti-inflammatory potential of berberine in vitro and in vivo. Cancer Lett. 2004;203(2):127-137. doi:10.1016/j. canlet.2003.09.002

55. Farhood B, Mortezaee K, Goradel NH, et al. Curcumin as an anti-inflammatory agent: implications to radiotherapy and chemotherapy. $J$ Cell Physiol. 2019;234(5):5728-5740. doi:10.1002/jcp.27442

56. Dorsch W, Stuppner H, Wagner H, Gropp M, Demoulin S, Ring J. Antiasthmatic effects of Picrorhiza kurroa: androsin prevents allergen- and PAF-induced bronchial obstruction in Guinea pigs. Int Arch Allergy Appl Immunol. 1991;95(2-3):128-133. doi:10.1159/000235416

57. Wang X, Feng S, Ding N, et al. Anti-inflammatory effects of berberine hydrochloride in an LPS-induced murine model of mastitis. Evid Based Complement Alternat Med. 2018;2018:5164314. doi:10.1155/2018/5164314

58. Kim S, Kim Y, Kim JE, Cho KH, Chung JH. Berberine inhibits TPA-induced MMP-9 and IL-6 expression in normal human keratinocytes. Phytomedicine. 2008;15(5):340-347. doi:10.1016/j.phymed.2007.09.011

59. Balkrishna A, Pokhrel S, Tomer M, et al. Anti-acetylcholinesterase activities of mono-herbal extracts and exhibited synergistic effects of the phytoconstituents: a biochemical and computational study. Molecules. 2019;24:22. doi:10.3390/molecules24224175

60. Kim-Park WK, Allam ES, Palasuk J, Kowolik M, Park KK, Windsor LJ. Green tea catechin inhibits the activity and neutrophil release of Matrix Metalloproteinase-9. J Tradit Complement Med. 2016;6(4):343-346. doi:10.1016/j.jtcme.2015.02.002

61. Huang MT, Liu Y, Ramji D, et al. Inhibitory effects of black tea theaflavin derivatives on 12-O-tetradecanoylphorbol-13-acetate-induced inflammation and arachidonic acid metabolism in mouse ears. Mol Nutr Food Res. 2006;50(2):115-122. doi:10.1002/mnfr.200500101

62. Junghans V, Gutgesell C, Jung T, Neumann C. Epidermal cytokines IL-1beta, TNF-alpha, and IL-12 in patients with atopic dermatitis: response to application of house dust mite antigens. J Invest Dermatol. 1998;111(6):1184-1188. doi:10.1046/j.1523-1747.1998.00409.x

63. Oxholm A. Epidermal expression of interleukin-6 and tumour necrosis factor-alpha in normal and immunoinflammatory skin states in humans APMIS Suppl. 1992;24:1-32.

64. Asahina R, Maeda S. A review of the roles of keratinocyte-derived cytokines and chemokines in the pathogenesis of atopic dermatitis in humans and dogs. Vet Dermatol. 2017;28(1):16-e15. doi:10.1111/vde.12351

65. Toshitani A, Ansel JC, Chan SC, Li SH, Hanifin JM. Increased interleukin 6 production by T cells derived from patients with atopic dermatitis. J Invest Dermatol. 1993;100(3):299-304. doi:10.1111/1523-1747.ep12469875

66. Hunter CA, Jones SA. Corrigendum: IL-6 as a keystone cytokine in health and disease. Nat Immunol. 2017;18(11):1271. doi:10.1038/ni1117-1271b

67. Kang D, Li B, Luo L, et al. Curcumin shows excellent therapeutic effect on psoriasis in mouse model. Biochimie. 2016;123:73-80. doi:10.1016/j. biochi.2016.01.013

68. Huang MT, Lysz T, Ferraro T, Abidi TF, Laskin JD, Conney AH. Inhibitory effects of curcumin on in vitro lipoxygenase and cyclooxygenase activities in mouse epidermis. Cancer Res. 1991;51(3):813-819.

69. Tsang MS, Jiao D, Chan BC, et al. Anti-inflammatory activities of pentaherbs formula, berberine, gallic acid and chlorogenic acid in atopic dermatitis-like skin inflammation. Molecules. 2016;21(4):519. doi:10.3390/molecules21040519

70. Trush MA, Egner PA, Kensler TW. Myeloperoxidase as a biomarker of skin irritation and inflammation. Food Chem Toxicol. 1994;32(2):143-147. doi:10.1016/0278-6915(94)90175-9

71. Prateeksha S, Yusuf MA, Singh BN, et al. Chrysophanol: a natural anthraquinone with multifaceted biotherapeutic potential. Biomolecules. 2019;9 (2):68. doi:10.3390/biom9020068

72. Jeong HJ, Kim HY, Kim HM. Molecular mechanisms of anti-inflammatory effect of chrysophanol, an active component of AST2017-01 on atopic dermatitis in vitro models. Int Immunopharmacol. 2018;54:238-244. doi:10.1016/j.intimp.2017.11.019

73. Yuan K, Zhu Q, Lu Q, et al. Quercetin alleviates rheumatoid arthritis by inhibiting neutrophil inflammatory activities. J Nutr Biochem. 2020;84:108454. doi:10.1016/j.jnutbio.2020.108454

74. Beken B, Serttas R, Yazicioglu M, Turkekul K, Erdogan S. Quercetin improves inflammation, oxidative stress, and impaired wound healing in atopic dermatitis model of human keratinocytes. Pediatr Allergy Immunol Pulmonol. 2020;33(2):69-79. doi:10.1089/ped.2019.1137 


\section{Publish your work in this journal}

Clinical, Cosmetic and Investigational Dermatology is an international, peer-reviewed, open access, online journal that focuses on the latest clinical and experimental research in all aspects of skin disease and cosmetic interventions. This journal is indexed on CAS. The manuscript management system is completely online and includes a very quick and fair peer-review system, which is all easy to use. Visit http://www. dovepress.com/testimonials.php to read real quotes from published authors.

Submit your manuscript here: https://www.dovepress.com/clinical-cosmetic-and-investigational-dermatology-journal 